\title{
Sources of organic ice nucleating particles in soils
}

\author{
Tom C. J. Hill ${ }^{1}$, Paul J. DeMott ${ }^{1}$, Yutaka Tobo ${ }^{2,3}$, Janine Fröhlich-Nowoisky ${ }^{4}$, Bruce F. Moffett ${ }^{5}$, Gary D. Franc ${ }^{6, \dagger}$, \\ and Sonia M. Kreidenweis ${ }^{1}$ \\ ${ }^{1}$ Department of Atmospheric Science, Colorado State University, Fort Collins, CO, 80523, USA \\ ${ }^{2}$ National Institute of Polar Research, Tachikawa, Tokyo 190-8518, Japan \\ ${ }^{3}$ Department of Polar Science, School of Multidisciplinary Sciences, SOKENDAI (the Graduate University for Advanced \\ Studies), Tachikawa, Tokyo 195-8518, Japan \\ ${ }^{4}$ Multiphase Chemistry, Max Planck Institute for Chemistry, Mainz, 55020, Germany \\ ${ }^{5}$ Ocean Lab, Goodwick, SA64 0DE, UK \\ ${ }^{6}$ Plant Sciences Department, University of Wyoming, Laramie, WY, 82071, USA \\ $\dagger$ deceased
}

Correspondence to: Tom C. J. Hill (thomas.hill@ colostate.edu)

Received: 1 January 2016 - Published in Atmos. Chem. Phys. Discuss.: 19 January 2016

Revised: 1 May 2016 - Accepted: 16 May 2016 - Published: 10 June 2016

\begin{abstract}
Soil organic matter (SOM) may be a significant source of atmospheric ice nucleating particles (INPs), especially of those active $>-15^{\circ} \mathrm{C}$. However, due to both a lack of investigations and the complexity of the SOM itself, the identities of these INPs remain unknown. To more comprehensively characterize organic INPs we tested locally representative soils in Wyoming and Colorado for total organic INPs, INPs in the heat-labile fraction, ice nucleating (IN) bacteria, IN fungi, IN fulvic and humic acids, IN plant tissue, and ice nucleation by monolayers of aliphatic alcohols. All soils contained $\approx 10^{6}$ to $\approx 5 \times 10^{7} \mathrm{INPs} \mathrm{g}^{-1}$ dry soil active at $-10^{\circ} \mathrm{C}$. Removal of SOM with $\mathrm{H}_{2} \mathrm{O}_{2}$ removed $\geq 99 \%$ of INPs active $>-18^{\circ} \mathrm{C}$ (the limit of testing), while heating of soil suspensions to $105^{\circ} \mathrm{C}$ showed that labile INPs increasingly predominated $>-12^{\circ} \mathrm{C}$ and comprised $\geq 90 \%$ of INPs active $>-9^{\circ} \mathrm{C}$. Papain protease, which inactivates IN proteins produced by the fungus Mortierella alpina, common in the region's soils, lowered INPs active at $\geq-11^{\circ} \mathrm{C}$ by $\geq 75 \%$ in two arable soils and in sagebrush shrubland soil. By contrast, lysozyme, which digests bacterial cell walls, only reduced INPs active at $\geq-7.5$ or $\geq-6^{\circ} \mathrm{C}$, depending on the soil. The known IN bacteria were not detected in any soil, using PCR for the ina gene that codes for the active protein. We directly isolated and photographed two INPs from soil, using repeated cycles of freeze testing and subdivision of droplets of dilute soil suspensions; they were complex and apparently organic entities. Ice nucleation activity was not
\end{abstract}

affected by digestion of Proteinase K-susceptible proteins or the removal of entities composed of fulvic and humic acids, sterols, or aliphatic alcohol monolayers. Organic INPs active colder than -10 to $-12{ }^{\circ} \mathrm{C}$ were resistant to all investigations other than heat, oxidation with $\mathrm{H}_{2} \mathrm{O}_{2}$, and, for some, digestion with papain. They may originate from decomposing plant material, microbial biomass, and/or the humin component of the SOM. In the case of the latter then they are most likely to be a carbohydrate. Reflecting the diversity of the SOM itself, soil INPs have a range of sources which occur with differing relative abundances.

\section{Introduction}

We have known for more than 4 decades that soils are reservoirs of organic ice nucleating particles (INPs) (Vali, 1968; Schnell and Vali, 1972, 1973, 1976). Decaying leaf litter was found to produce up to $10^{10}$ INPs per gram active at $-10^{\circ} \mathrm{C}$, with an onset of activity at up to $\approx-1.5^{\circ} \mathrm{C}$ (Schnell and Vali, 1972, 1973). Rich top soils and peat were shown to be ice nucleating (IN) at $-4{ }^{\circ} \mathrm{C}$ (Vali, 1968). The component responsible for the highest temperatures of freezing, an IN bacterium, was soon isolated (Maki et al., 1974; Vali et al., 1976). However, the proposal (Schnell and Vali, 1972) that particles composed of soil organic matter (SOM) may act as INPs was contested (Rosinski et al., 1974) and then neglected 
as a topic for investigation, even though the aerial release of INPs from litters (Schnell and Vali, 1976) suggested that this may be a significant atmospheric source, especially of INPs active $\geq-10^{\circ} \mathrm{C}$. INPs influence cloud microphysical and radiative properties, the release of latent heat, and the triggering of precipitation.

Recently there has been a resurgence of related research, with the general aims of correlating abundances of organic INPs in the boundary layer with local ecotypes (Prenni et al., 2009; Bowers et al., 2010; Garcia et al., 2012; Huffman et al., 2013; Tobo et al., 2013; Mason et al., 2015), gauging the stimulation of their release by humidity, rainfall, and harvesting (Garcia et al., 2012; Huffman et al., 2013; Prenni et al., 2013; Wright et al., 2014; Bigg et al., 2015), and measuring organic INP abundance in clouds and precipitation (Christner et al., 2008; Delort et al., 2010; Joly et al., 2014; Monteil et al., 2014; Morris et al., 2008; Petters and Wright, 2015; Šantl-Temkiv et al., 2015).

By contrast, limited progress has been made in characterizing the nature of these "bio-INPs". Heating to $90-100{ }^{\circ} \mathrm{C}$ to deactivate IN macromolecules and digestion with $\mathrm{H}_{2} \mathrm{O}_{2}$ to entirely remove the SOM confirmed their dominance of the INP population active $\approx>-15^{\circ} \mathrm{C}$ in diverse sieved soils (Conen et al., 2011; O'Sullivan et al., 2014). Further, in dusts generated from Wyoming agricultural soils, treatment with heat $\left(300{ }^{\circ} \mathrm{C}\right)$ and $\mathrm{H}_{2} \mathrm{O}_{2}$ digestion revealed that organic-rich INPs predominated at all tested temperatures $>-36{ }^{\circ} \mathrm{C}$ (Tobo et al., 2014). Recent investigations into specific sources of organic INPs found that the soil-inhabiting fungus Mortierella alpina, which is common in many of the soils studied here, is an ice nucleator: all strains tested initiated freezing at -5 to $-6^{\circ} \mathrm{C}$ and released large numbers of cell-free INPs (Fröhlich-Nowoisky et al., 2015). Of potential widespread relevance, too, is the recent discovery of ice nucleation by cellulose (Hiranuma et al., 2015a): activity was detected starting at $-16^{\circ} \mathrm{C}$.

To more comprehensively assess the identities of organic INPs in soils, we tested soils representative of local ecotypes in Wyoming and Colorado for the presence of INPs from a wide range of potential sources. We tested for total organic INPs, INPs in the heat-labile fraction, IN bacteria (using PCR of the ina gene that codes for the Ina protein; Warren, 1995), IN $M$. alpina (by digestion with papain protease), IN fulvic and humic acids (via acid and alkaline extractions), ice nucleating entities comprised of crystals of sterols or monolayers of aliphatic alcohols (by removal with chloroform), and IN plant tissue. We also demonstrated that cycles of freezetesting and subdivision of droplets of dilute soil suspensions can be used to directly isolate individual INPs from soil for subsequent analyses.

\section{Materials and methods}

\subsection{Soil sampling}

Topsoils were sampled from beneath representative natural ecotypes and land uses, mostly in Wyoming. These included conventionally and organically cropped land and pasture at the University of Wyoming's Sustainable Agricultural Research and Extension Center (SAREC), near Lingle, Wyoming, sagebrush shrubland, native glacial scree grassland and lodgepole pine forest in south-east Wyoming, and ponderosa pine forest at the Manitou Experimental Forest Observatory (MEFO) (Ortega et al., 2014) in Colorado. Details of sites and vegetation are given in Table 1. At each site, three replicate soil samples were obtained. Each was obtained from a separate $10 \times 10 \mathrm{~m}$ area, and within each area three cores, each $5 \mathrm{~cm}$ deep and $\approx 10 \mathrm{~cm}$ in diameter, were retrieved and mixed together on site. Samples were thoroughly mixed, any stones (no soils had smaller, gravelsized pieces) and roots were removed, and then the samples were stored at $4{ }^{\circ} \mathrm{C}$ before testing. Sub-samples were frozen in airtight $15 \mathrm{~mL}$ screw-cap tubes at $-20^{\circ} \mathrm{C}$ for DNA extractions and papain digestions.

Dry weights were obtained by heating a sub-sample of each soil to $105^{\circ} \mathrm{C}$ for $24 \mathrm{~h}$. For analysis of soil organic carbon and total nitrogen only, sub-samples of soils with a $\mathrm{pH}>7$ were initially immersed in $0.1 \mathrm{M} \mathrm{HCl}$ overnight to remove carbonates and then filtered (no. 42 paper, Whatman) and dried as above. Samples were ground and sieved through a $0.5 \mathrm{~mm}$ sieve and analysed using a $\mathrm{CHN}$ analyser.

\subsection{Measurement of INPs}

Concentrations of INPs in soil suspensions were derived using the immersion freezing method. Samples were made initially into a 10-fold slurry with INP-free diluent, mixed on an orbital shaker at $200 \mathrm{rpm}$ for $20 \mathrm{~min}$ and then a series of 10 fold dilutions constructed. INP estimates were made using 32 aliquots of $50-80 \mu \mathrm{L}$ of suspension dispensed into sterile 96well polypropylene PCR trays (Life Science Products Inc.). Full details of the immersion freezing protocol are given in Garcia et al. (2012) but are summarized here. INP numbers were estimated by counting the number of frozen aliquots in the PCR tray as it was cooled in a thermal cycler (PTC-200, MJ Research). The cycler was programmed to descend in 0.5 or $1^{\circ} \mathrm{C}$ increments with a $5 \mathrm{~min}$ dwell time at each temperature. Once at $-9^{\circ} \mathrm{C}$ (the limit of this device) the tray was transferred to a 96-well aluminium incubation block (VWR) cooled to $\approx-12{ }^{\circ} \mathrm{C}$ inside a foam box in a freezer. A thermistor was inserted into a side well and after $10 \mathrm{~min}$ of further incubation in the freezer the block temperature and number of frozen wells was recorded. The tray was then transferred to two further blocks at sequentially colder temperatures (down to $\approx-20^{\circ} \mathrm{C}$ ). Holding times at each temperature were chosen based on observations of the time required for essentially 


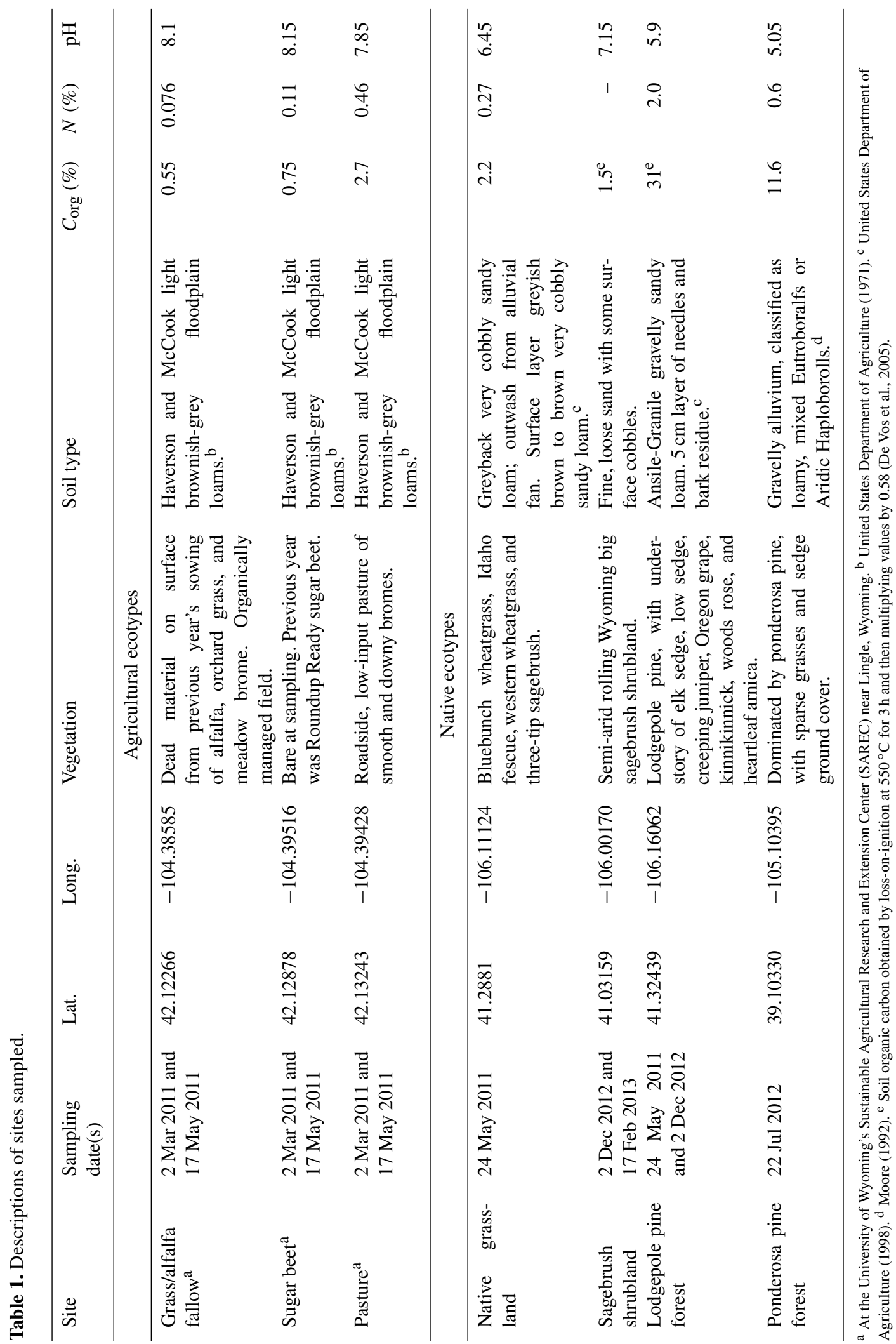


full expression of ice nucleation activity, and they may produce slightly higher concentrations than methods using faster ramp rates.

Results were adjusted for INPs in the diluent (INP-free until $<-15^{\circ} \mathrm{C}$ ). The effect of papain digestion was assessed using CSU's ice spectrometer, a method that eliminates the transfer procedures used in the above method (details of the method are given in Hiranuma et al., 2015b). Numbers of INPs in soil suspensions were estimated using Eq. (1):

INPs $\left[\mathrm{mL}^{-1}\right]=\frac{-\ln (f)}{V}$,

where $f$ is the proportion of droplets not frozen and $V$ is the volume of each aliquot (Vali, 1971), and INPs per $\mathrm{mL}$ of soil suspension were converted to INPs $\mathrm{g}^{-1}$ of dry soil. Confidence intervals $(95 \%)$ were derived using the formula (no. 2) recommended by Agresti and Coull (1998).

\subsection{Removal of SOM}

Removal of SOM was achieved by digestion with hydrogen peroxide. Fifty millilitres of $15 \% \mathrm{H}_{2} \mathrm{O}_{2}$ were added to 2.5$10 \mathrm{~g}$ fresh soil; the slurry was steeped until initial foaming subsided and then boiled while topping up with $\mathrm{H}_{2} \mathrm{O}_{2}$ as required until all SOM and then all residual $\mathrm{H}_{2} \mathrm{O}_{2}$ were decomposed (but see Mikutta et al., 2005, for a review of the inefficiencies inherent in the use of oxidizers to remove SOM from soils). Suspensions were left overnight to settle, the $\mathrm{pH}$ restored if necessary (drop-wise addition of $1 \mathrm{M} \mathrm{NaOH}$ to the pasture soil and $1 \mathrm{M} \mathrm{HCl}$ to the kaolinite), and the volume made up to a 10-fold dilution with deionized water. Ten-fold serial dilutions were then made using $0.45 \mu \mathrm{m}$ pore diameter filtered $10 \mathrm{mM}$ sodium phosphate buffer $(\mathrm{pH} 7)$ or deionized water as the diluents (comparison tests showed no difference).

For the sugar beet and organic grass/alfalfa fallow soils and kaolinite, a comparison of INP concentrations was made for the untreated and $\mathrm{H}_{2} \mathrm{O}_{2}$ digested samples with comparably treated aerosolized soil dusts $(0.6 \mu \mathrm{m}$ diameter $)$ measured using a continuous flow diffusion chamber (Tobo et al., 2014). INP fraction data presented by Tobo et al. (2014) were converted to per gram values, assuming the particles were spherical and had a density of $2.6 \mathrm{~g} \mathrm{~cm}^{-3}$.

\subsection{Removal of humics}

Testing for INPs of humic origin was performed on the SAREC pasture soil since it contained $\approx 5 \%$ SOM and a commensurately high level of INPs. Fulvic and humic acids were removed using the International Humic Substance Society method as described in Swift (1996). Briefly, $1 \mathrm{M} \mathrm{HCl}$ and deionized water were added to a sample until a $10: 1$ liquid : dry-soil weight ratio until a $\mathrm{pH}$ of $\approx 1.5$ was obtained. The suspension was shaken for $1 \mathrm{~h}$, settled, and the lightly coloured supernatant decanted off. The sediment was neutralized with $1 \mathrm{M} \mathrm{NaOH}$ and then $0.1 \mathrm{M} \mathrm{NaOH}$ was added until a 10:1 liquid: dry-soil weight ratio was reached. This was shaken intermittently for $4 \mathrm{~h}$, settled overnight, and the now dark brown supernatant containing the humic acids removed by decanting. Suspensions of the residual soil were then made in $0.45 \mu \mathrm{m}$ pore diameter filtered $10 \mathrm{mM}$ sodium phosphate buffer at a $\mathrm{pH}$ value approximating the soil sample and tested for INP content.

\subsection{Removal of sterols and aliphatics}

Two contrasting soils, the organic horizon from the lodgepole pine forest and the sagebrush shrubland soil, were tested for ice nucleating entities sourced from monolayers of alcohols, sterol crystals, and other chloroform-soluble organics. This was assessed by dissolving the organics and testing for any decrease in ice nucleation activity. Soils were airdried and then $\approx 5 \mathrm{~g}$ added to $30 \mathrm{~mL}$ chloroform; the mix was shaken and then steeped for 3 days before removing the chloroform by vacuum filtration using a glass filter holder fitted with a $0.45 \mu \mathrm{m}$ pore diameter cellulose filter (Gelman). Samples were then rinsed three times with fresh chloroform and dried overnight. Suspensions of the soils were made in buffer $(10 \mathrm{mM}$ sodium phosphate buffer at $\mathrm{pH}$ values approximating the original soil sample and filtered through a $0.1 \mu \mathrm{m}$ pore diameter syringe filter (Nalgene, Thermo Scientific) and tested for INP content.

\subsection{Heat treatments}

Ice nucleating particles produced by IN bacteria and fungi (probably including lichen symbionts) are typically proteins (see Pummer et al., 2015). Protein function is controlled by secondary and tertiary structures and in IN bacteria also by the formation of complexes (e.g. Kozloff et al., 1991; Schmid et al., 1997; Garnham et al., 2011). Heat is a simple but effective tool to disrupt and denature these proteinaceous INP. Two temperatures, 60 and $105^{\circ} \mathrm{C}$, were used.

Sixty degrees Celsius is a moderate heat that will fragment molecular complexes and denature heat-labile proteins. Accordingly, in tests on diverse IN bacteria isolated from crops and grasses, incubation at $60^{\circ} \mathrm{C}$ for $20 \mathrm{~min}$ degraded INPs from class A aggregates nucleating $\geq-3^{\circ} \mathrm{C}$ to class $\mathrm{C}$ oligomers typically freezing at -8 to $-9^{\circ} \mathrm{C}$ (Turner et al., 1990; Hill et al., 2014), while $60^{\circ} \mathrm{C}$ for $60 \mathrm{~min}$ deactivated the INPs of the IN fungi Acremonium implicatum and Isaria farinosa (Pummer et al., 2015) isolated from boundary layer air in Colorado (Huffman et al., 2013). INPs produced by bacteria and fungi are, however, often unaffected by this temperature. This includes leaf-derived ice nuclei (Schnell and Vali, 1973), most strains of IN M. alpina (FröhlichNowoisky et al., 2015), IN lichen (Kieft and Ruscetti, 1990), and IN Fusarium spp. (Pouleur et al., 1992), although the onset temperature of activity of cell-free INPs of $F$. avenaceum was lowered when heated $>40^{\circ} \mathrm{C}$ (Hasegawa et al., 1994). It should also be noted that immobilization of proteins onto 
clays or tannins can significantly affect their sensitivity (either increase or decrease) to denaturation by $60^{\circ} \mathrm{C}$ heat (Rao et al., 2000). To test the sensitivity of soil INPs to moderate heat, PCR trays were thawed after initial INP testing and then heated in the thermal cycler to $60^{\circ} \mathrm{C}$ for $20 \mathrm{~min}$ and retested.

To test the effect of a more denaturing heat, $1.8 \mathrm{~mL}$ of a 100-fold dilution of soil suspension was aliquoted into a $2 \mathrm{~mL}$ screw-cap microcentrifuge tube and immersed in mineral oil at $105^{\circ} \mathrm{C}$ for $20 \mathrm{~min}$ (plus $7 \mathrm{~min}$ for equilibration). Serial dilutions were made with $0.45 \mu \mathrm{m}$ pore size filtered $10 \mathrm{mM}$ sodium phosphate buffer (at $\mathrm{pH}$ values approximating the original soil sample).

\subsection{Enzymatic digestions}

The enzyme lysozyme lyses all bacteria by digesting the cell wall polymer peptidoglycan. It also hydrolyses fungal chitin oligosaccharides but not the chitin polymer itself. Gramnegative bacteria such as the IN bacteria are less susceptible to lysozyme digestion of their cell walls than Gram-positives because their outer membrane acts as a barrier and because their cell walls have less peptidoglycan. Their efficient lysis requires EDTA which, by compromising the integrity of the outer membrane, assists the passage of lysozyme. Tests on pure cultures of diverse IN bacterial isolates grown in nutrient broth, with cell densities measured using absorbance at $600 \mathrm{~nm}$, confirmed that addition of EDTA was required (optimal at $5 \mathrm{mM}$ ) for efficient lysis with lysozyme at $4 \mathrm{mg} \mathrm{mL}^{-1}$ (Pooley and Brown, 1990), a concentration comparable to that used by Christner et al. (2008). A series of soil suspensions ranging in dilution from $10^{-2}$ to $10^{-7}$ were constructed in $0.45 \mu \mathrm{m}$ pore diameter filtered $10 \mathrm{mM}$ Tris $(\mathrm{pH} 8), 5 \mathrm{mM}$ EDTA (pH 8), and $4 \mathrm{mg} \mathrm{mL}^{-1}$ lysozyme (L7651, SigmaAldrich) and incubated at $16^{\circ} \mathrm{C}$ for $24 \mathrm{~h}$. The control comprised soil suspensions in Tris and EDTA incubated under the same conditions.

To test soils for the presence of INPs susceptible to digestion by Proteinase K, such as those possessed by IN Fusarium species (Hasegawa et al., 1994; Humphreys et al., 2001), suspensions of the agricultural soils were digested with $5 \mathrm{U} \mathrm{mL}^{-1}$ Proteinase $\mathrm{K}$ (Qiagen) using the same buffer, incubation conditions and negative controls as used for lysozyme (also optimal for this enzyme). Soil suspensions ( 1 in 20 dilution) were also digested with papain protease (AppliChem) at concentrations of 10 or $20 \mathrm{mg} \mathrm{mL}^{-1}$ in $10 \mathrm{mM}$ sodium phosphate buffer $(\mathrm{pH} 6.3)$ at $60^{\circ} \mathrm{C}$ for $20 \mathrm{~min}$. Controls were again processed in the same manner except without the enzyme. The INP-free buffer was used for serial dilutions for INP determinations.

Adsorption of enzymes onto the surfaces of minerals, with consequent deactivation of their IN sites, as observed by Zolles et al. (2015), does not appear to have been a factor in the soils tested; lysozyme and Proteinase $\mathrm{K}$ had no effect upon INP counts below their expected impacts at relatively warm temperatures.

\subsection{PCR of the ina gene in IN bacteria}

For DNA extraction, $2 \mathrm{~g}$ of soil was mixed into a thick slurry with deionized water $(18.2 \mathrm{M} \Omega$ and $0.2 \mu \mathrm{m}$ filtered) and $50 \mu \mathrm{L}$ transferred to the DNA extraction tube. For the lodgepole pine forest litter, $2 \mathrm{~g}$ was mixed with $40 \mathrm{~mL}$ deionized water, shaken for $20 \mathrm{~min}$ at $250 \mathrm{rpm}$, then $0.5 \mathrm{~mL}$ transferred to a $1.5 \mathrm{~mL}$ microfuge tube, spun at $22500 \mathrm{~g}$ for $5 \mathrm{~min}$, and had all but $50 \mu \mathrm{L}$ of the supernatant removed. This was then transferred to the DNA extraction tube using solution MD1 of the DNA extraction kit. DNA extraction was performed using the recommended protocol of the PowerLyzer ${ }^{\mathrm{TM}}$ UltraClean ${ }^{\circledR}$ Microbial DNA Isolation Kit (MO BIO Laboratories Inc.), with homogenization on a FastPrep ${ }^{\circledR}$ bead beater (BIO 101 Inc.) at setting 4 for 5 min.

Quantitative PCR of the ina gene was initially attempted using the method described in Hill et al. (2014). However, a lack of detectable amplicons in any samples combined with the high diversity of soil genomic DNA led to significant mispriming, which limited the method's sensitivity. We therefore spiked standard ina gene PCRs with a range of known ina gene copies and used detection of a discernible amplicon on gels to gauge the approximate limits of detection.

Each PCR contained $1 \mathrm{U}$ of GoTaq ${ }^{\circledR}$ Hot Start Polymerase (Promega) in $1 \times$ Colorless GoTaq ${ }^{\circledR}$ Flexi Buffer (no $\mathrm{Mg}$ in buffer), $0.9 \mu \mathrm{M}$ forward primer $3308 \mathrm{f}$ (5 GGCGATMGVAGCAAACTSAC 3), $0.9 \mu \mathrm{M}$ reverse primer $3462 \mathrm{r} 1$ (5 TGTAVCKTTTSCCGTCCCAG 3), $0.2 \mathrm{mM}$ each dNTP, $1.25 \mathrm{mM} \mathrm{MgCl}_{2}, 4 \%$ DMSO, $2 \mu \mathrm{L}$ of DNA extract, $0.5 \mu \mathrm{L}$ ina gene spike, and deionized water to a total volume of $25 \mu \mathrm{L}$. Spikes ranged from 60 to 1185 ina gene copies using genomic DNA extracted from a pure culture of $P$. syringae Cit7 (see Hill et al., 2014, for details of the isolate and culturing and preparation of standards).

Cycling conditions were an initial denaturation at $95^{\circ} \mathrm{C}$ for $2 \mathrm{~min}$, followed by 40 cycles of $94^{\circ} \mathrm{C}$ for $15 \mathrm{~s}$ and $54^{\circ} \mathrm{C}$ for $25 \mathrm{~s}$ (combined primer annealing and extension). Amplification was performed on a Bio-Rad DNAEngine ${ }^{\circledR}$ (Hercules). After amplification, products (194 bp) were electrophoresed in $1.5 \%$ MetaPhor $^{\circledR}$ agarose gels (Cambrex) in $1 \times$ sodium borate buffer at $200 \mathrm{~V}$ for $35 \mathrm{~min}$, using ethidium bromide for visualization. A 50 bp ladder (G4521, Promega) was used for sizing. Presence of an unambiguous amplicon on gels was used to estimate the limit of detection of ina genes for each soil's DNA and converted to theoretical upper limits of IN bacteria per gram dry soil (there is one copy of the ina gene per bacterium).

\subsection{Direct isolation of INPs from soil}

Freezing triggered by an INP can be exploited as a means to isolate it. Initially, a $10^{-5}$ dilution of sagebrush soil was prepared in $0.2 \mu \mathrm{m}$ pore diameter filtered deionized water. Then, $50 \mu \mathrm{L}$ aliquots were dispensed into a 96-well PCR tray and the tray cooled to $-7.0^{\circ} \mathrm{C}$. Frozen wells were noted and the 
plate thawed. The contents of a well that froze was transferred to a sterile microplate lid (Nunc, Thermo Scientific) and divided into an array of $1 \mu \mathrm{L}$ droplets. The plate was covered, placed on a cold block at $\approx-15{ }^{\circ} \mathrm{C}$ for $10 \mathrm{~min}$, uncovered, and, using a stereo microscope, the single frozen droplet was noted. The plate was warmed, $2-4 \mu \mathrm{L}$ of deionized water added to the frozen droplet, and the droplet then divided into an array of 0.1 or $0.2 \mu \mathrm{L}$ droplets for freeze testing. This cycle was repeated $2-3$ further times. The lid was then transferred to a microscope, the droplet containing the INP observed as it evaporated, and the residual photographed.

\subsection{Ice nucleation by sagebrush tissues}

The semi-arid sagebrush shrubland soil had a particularly pronounced onset of ice nucleation activity, increasing from $\approx 30$ to almost a million INPs ${ }^{-1}$ soil between -5 and $-6^{\circ} \mathrm{C}$. This suggests a single class of INP was responsible. To test whether sagebrush tissues were the INPs responsible, shoots (leaves and small stems) and roots up to $1 \mathrm{~mm}$ diameter were collected at the sagebrush shrubland site in February 2013 and tested.

Foliage and roots were washed to remove loose soil, placed in fresh plastic bags filled with deionized water and sonicated for several minutes to further dislodge soil particles. The water was replaced and the process repeated five times for a total of $30 \mathrm{~min}$ of sonication. A subsample of each tissue type was then ground under liquid nitrogen in a pestle and mortar (cleaned by soaking in $5 \% \mathrm{H}_{2} \mathrm{O}_{2}$ for several hours followed by repeated rinses in deionized water). The ground root powder was examined under a microscope and contained root cell fragments plus bacteria and occasional pieces of fungal hyphae. Serial dilutions in deionized water were tested for INP content. A sample of the initial 50-fold dilution was re-tested after heating to $105^{\circ} \mathrm{C}$ for $15 \mathrm{~min}$ to determine INP heat sensitivity.

\section{Results and discussion}

All soils presented contained abundant INPs active at warm temperatures (Fig. 1). While the onset of nucleation ranged over $2.5^{\circ} \mathrm{C}$, all soils demonstrated a pronounced increase below $-5^{\circ} \mathrm{C}$, while below approximately $-8^{\circ} \mathrm{C}$ the rate of increase lessened to become progressively log-linear. INP concentrations at $-10^{\circ} \mathrm{C}$ ranged from $\approx 10^{6}$ to $\approx 5 \times 10^{7} \mathrm{~g}^{-1}$ dry soil, with levels in the native grassland and agricultural soils comparable to those found in grassland and agricultural topsoils in Germany, Hungary, and England (Conen et al., 2011; O'Sullivan et al., 2014, soils A, C, and D). INPs in the two pine forest litters were lower than reported for comparable USA High Plains litters by Schnell and Vali (1976); they noted they were similar to values of $\approx 10^{9} \mathrm{INPs}^{-1}$ fresh litter found in D-type vegetation. However, this High Plains

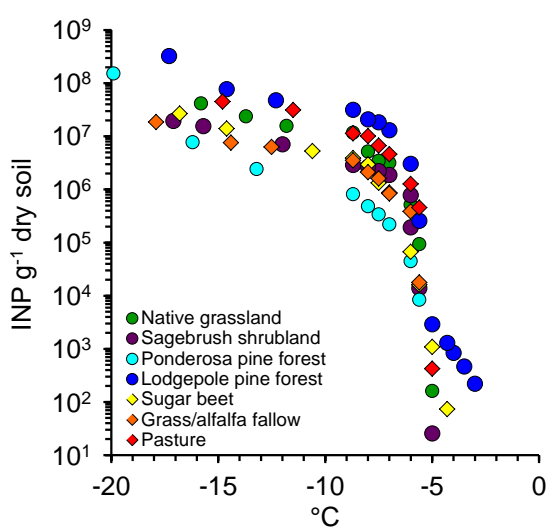

Figure 1. Ice nucleating particle concentrations in four natural ecotype and three agricultural soils.

litter may also have included deciduous plant litter (Russell Schnell, personal communication, 2016). Unexpectedly, the lowest concentrations were found in ponderosa pine forest litter, even though the organic matter content of this sample was high $(\approx 20 \%$, Table 1$)$. INP production by soils and litters is thus not only a function of climatic region (Schnell and Vali, 1976) and SOM content (Conen et al., 2011) but also dependent upon the resource quality of the SOM supplied by the vegetation, among other factors.

\subsection{INPs in the total soil organic matter}

Reductions in INPs caused by SOM removal with $\mathrm{H}_{2} \mathrm{O}_{2}$ (Fig. 2) were similar to or greater than those found by $\mathrm{Co}$ nen et al. (2011) and greater than those found by O'Sullivan et al. (2014), who used a gentler peroxide treatment. At the lower temperature limit $\left(-15\right.$ to $\left.-18^{\circ} \mathrm{C}\right)$, INPs were reduced by 2-3 orders of magnitude, comparable to the findings of Conen et al. (2011; soils B-D), but more than a 10-fold greater impact than observed by O'Sullivan et al. (2014). By contrast, no effect of $\mathrm{H}_{2} \mathrm{O}_{2}$ digestion was observed for kaolinite, in agreement with the results of Tobo et al. (2014) and as also found for the minerals montmorillonite and K-feldspar (Conen et al., 2011; O'Sullivan et al., 2014).

There was reasonable agreement between results obtained here, using immersion freezing on bulk soil suspensions, with INP spectra below $-18^{\circ} \mathrm{C}$ obtained from aerosolized soil dusts $(0.6 \mu \mathrm{m}$ diameter $)$ of the sugar beet and organic alfalfa fallow soils, and measured using the continuous flow diffusion chamber (Tobo et al., 2014) (Fig. 2). The closeness of the correspondence of spectra in agricultural soils may be partly fortuitous (due to several biases cancelling out each other's effects), since it is unlikely that $0.6 \mu \mathrm{m}$ diameter particles will possess the same INP-active fraction as whole soil. Of greater importance are the large reductions in INPs following $\mathrm{H}_{2} \mathrm{O}_{2}$ digestions in both sets of tests, suggesting that organic forms would also comprise the bulk of INPs active 

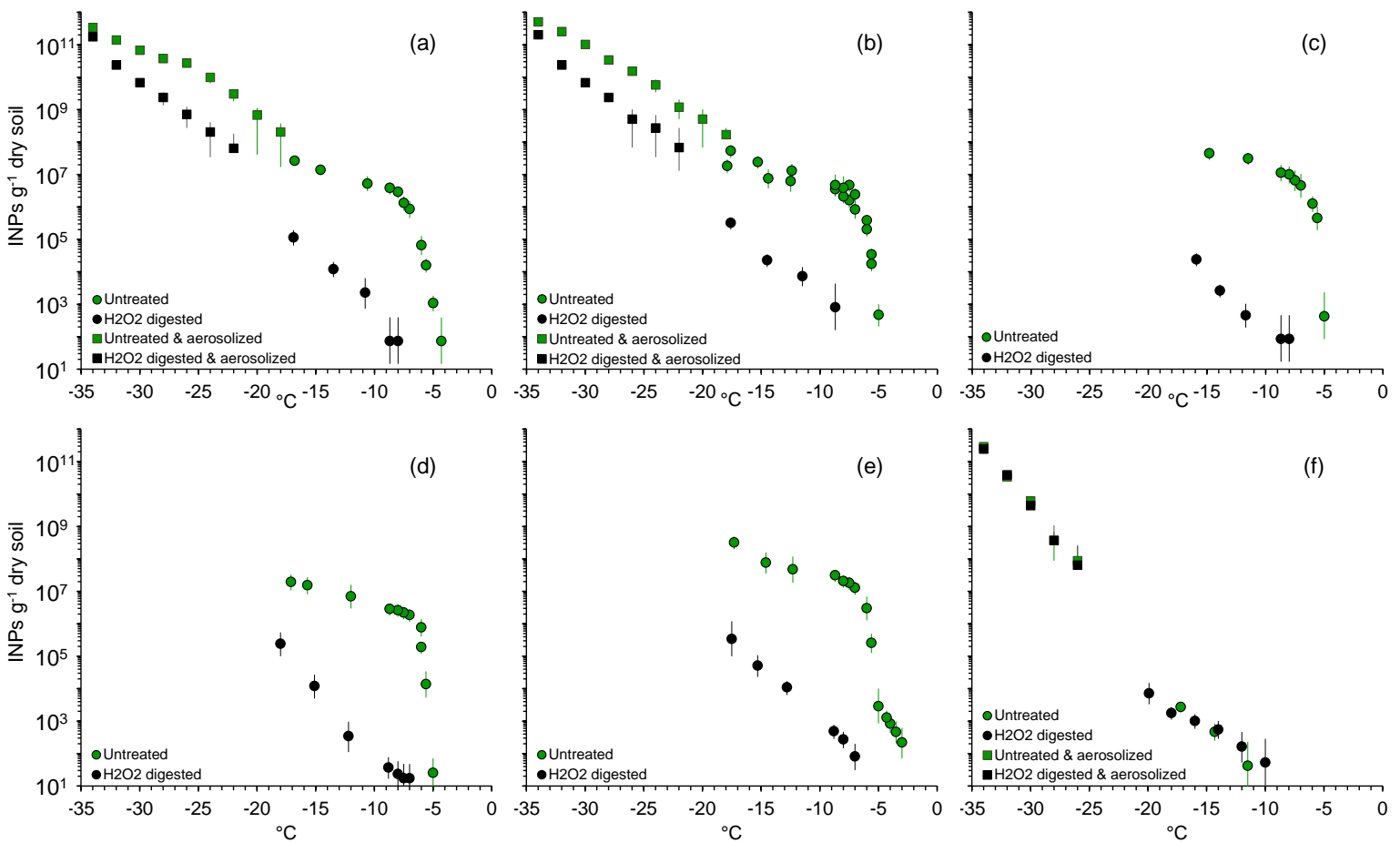

Figure 2. Effect of removal of SOM by $\mathrm{H}_{2} \mathrm{O}_{2}$ digestion upon INP concentrations of soils. Soils are (a) sugar beet, (b) organic grass/alfalfa fallow, (c) pasture, (d) sagebrush shrubland, (e) lodgepole pine forest, and (f) pure kaolinite. The sugar beet, organic grass/alfalfa, and kaolinite figures include data of aerosolized soil dusts $(0.6 \mu \mathrm{m}$ diameter) from Tobo et al. (2014) measured using a continuous flow diffusion chamber.

over a wide range of temperatures in dusts raised from these agricultural soils.

\subsection{INPs in fulvic and humic acids}

Soil organic matter comprises a spectrum of forms ranging from fresh plant inputs to ancient, refractory organic matter. It is often divided into the broad classes of decomposable plant material, resistant plant material, microbial biomass, humus, and inert organic matter (Coleman and Jenkinson, 1999). The humus fraction, a complex mixture of biologically transformed plant and microbial debris, usually predominates and has itself been classically sub-divided into three groups: fulvic acids, humic acids, and humin. Fulvic acids are the fraction that dissolve in $0.1 \mathrm{M} \mathrm{HCl}$, humic acids the fraction that subsequently solubilize in $0.1 \mathrm{M} \mathrm{NaOH}$, and humin the residue (Powlson et al., 2013). These three groups delineate broad and "operationally defined" - as opposed to "ecologically defined" - pools of humic substances (Wander, 2004).

Humic and fulvic acids are of particular interest because of their apparent similarity to atmospheric HULIS (HUmicLIke Substances), the often significant constituent in watersoluble organic carbon extracted from aerosols (Graber and Rudich, 2006; Wang and Knopf, 2011). However, Graber and Rudich (2006) concluded that HULIS are both smaller
(MW < 1000) and less aromatic than terrestrial humic substances and more likely to be the product of the oligomerization of smaller molecules while airborne or the breakdown and reassembly of fulvic and humic acids lofted from soil surfaces. HULIS thus appears to be similar to, but not the same as, humus. Studies using commercially available fulvic and humic acids as surrogates for HULIS found they possessed unremarkable ice nucleation activities (Kanji et al., 2008; O'Sullivan et al., 2014; Wang and Knopf, 2011). O'Sullivan et al. (2014) recorded the warmest activity with sieved suspensions: onset of activity for Suwannee River fulvic acid was $\approx-14{ }^{\circ} \mathrm{C}$ and for Leonardite humic acid it was $\approx-19^{\circ} \mathrm{C}$. Fornea et al. (2009) measured onset of freezing temperatures of $-10.5^{\circ} \mathrm{C}$ for Pahokee peat, but they used individual particles of the intact soil. It should be noted that the standard extraction method used would also solubilize and remove most atmospheric HULIS forms from the SOM (Feczko et al., 2007).

In the pasture soil, removal of fulvic acids had no apparent impact upon INPs, while removal of humic acids only reduced INPs active $\geq-7{ }^{\circ} \mathrm{C}$ (Fig. 3), and these may have been biological macromolecular INPs denatured by the $\mathrm{pH} 13$ extractant. The small molecular weights and the diversity of forms of fulvic and humic acids make it improbable that they posses significant ice nucleation activity. By contrast, the residual humin is compromised in large part of 

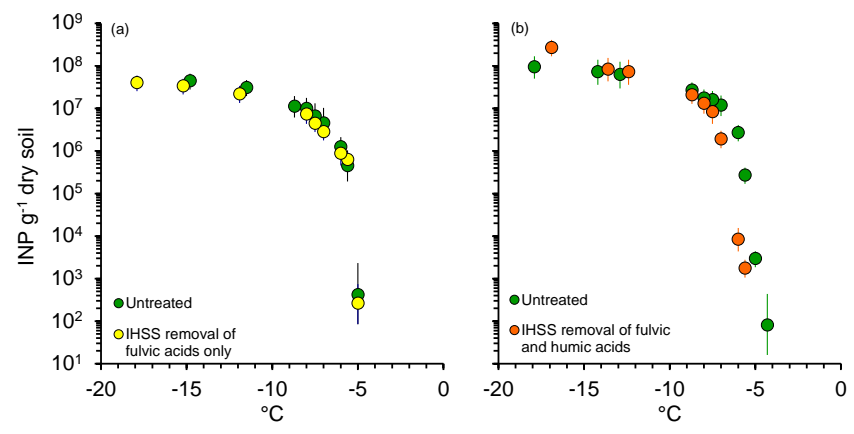

Figure 3. Effect of removal of fulvic (a) and both fulvic and humic (b) acids upon the INP content of the pasture soil.

macromolecules or aggregates of peptides, aliphatics, carbohydrates, lignin, and the bacterial cell wall polymer peptidoglycan (Simpson et al., 2007) and hence is a more likely source of IN molecules.

\subsection{INPs from sterols and monolayers of aliphatic alcohols}

Several classes of naturally occurring organic compounds are effective INPs (Bashkirova and Krasikov, 1957; Head, 1961, 1962; Fukuta, 1966). Crystals of some sterols, for example, trigger nucleation $>-5^{\circ} \mathrm{C}$, although the fungal sterol ergosterol and the plant sterol $\beta$-sitosterol were found to be inactive (Head, 1962; Fukuta and Mason, 1963).

Under optimal conditions, monolayers of aliphatic alcohols can also induce ice nucleation at temperatures ranging from $\approx-14{ }^{\circ} \mathrm{C}$ for $\mathrm{C}_{14} \mathrm{H}_{29} \mathrm{OH}$ to just below $-1{ }^{\circ} \mathrm{C}$ for $\mathrm{C}_{31} \mathrm{H}_{63} \mathrm{OH}$ (Gavish et al., 1990; Popovitz-Biro et al., 1994; see also Rosinski, 1980). Nucleation is facilitated by alcohols self-assembling into two-dimensional crystalline clusters on air: liquid or liquid : liquid interfaces, with their hydroxyl groups embedded into the water surface and arrayed with a spacing closely matching hexagonal ice (Gavish et al., 1990; Popovitz-Biro et al., 1991). In the two soils tested here, the removal of organics with chloroform had no significant effect upon the INP spectra (Fig. 4), suggesting that IN organic crystals or long-chain alcohols were not present or did not occur in sufficient quantities or the required purity.

\subsection{Heat-labile INPs}

As shown in Fig. 5, the $60^{\circ} \mathrm{C}$ treatment had essentially no impact upon the soils' INP activation temperature spectra, apart from some reduction $\geq-6{ }^{\circ} \mathrm{C}$ in the sugar beet and lodgepole pine soils. This general insensitivity suggests that labile IN proteins or protein complexes from IN bacteria or other microbial or plant sources were not present, or not significant contributors, of high-temperature INPs to the soils.

Heating suspensions of IN bacteria, isolated from crops at the agricultural research centre, to $105^{\circ} \mathrm{C}$ denatured and deactivated their Ina proteins (Hill et al., 2014). Likewise,

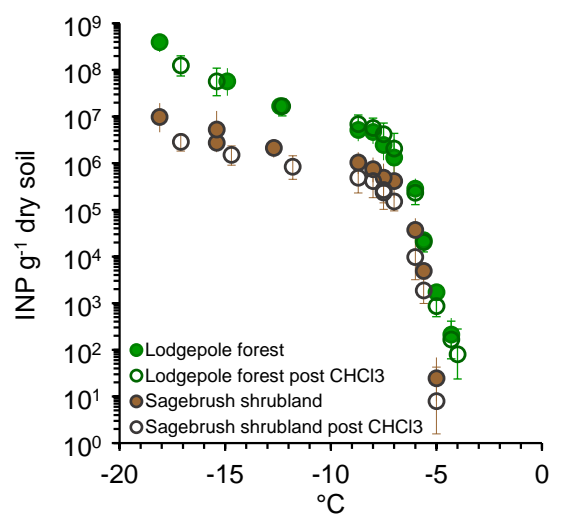

Figure 4. Effect of removal of organics, such as sterols and aliphatic alcohols, with chloroform upon INP temperature spectra of forest and shrubland soils.

$98^{\circ} \mathrm{C}$ treatment almost eliminated the ice nucleation activity of all but a couple of local isolates of IN M. alpina (FröhlichNowoisky et al., 2015), while $90^{\circ} \mathrm{C}$ heating lowered the median activity of IN $F$. avenaceum by $10^{\circ} \mathrm{C}$. Correspondingly, the $105^{\circ} \mathrm{C}$ treatment reduced the INP concentration active at $-9^{\circ} \mathrm{C}$ in all soils by $\geq 10$-fold. In the lodgepole pine litter this reduction extended to at least $-15^{\circ} \mathrm{C}$. Interestingly, for boundary layer aerosols collected above crops in northern Colorado (Garcia et al., 2012), the reduction in INPs following $98^{\circ} \mathrm{C}$ heating was similar to that found in these soils but, like with the lodgepole pine litter, extended further, to $\approx-18{ }^{\circ} \mathrm{C}$ (the limit of the measures in that study). In three out of the four soils tested by Conen et al. (2011) heating to $100^{\circ} \mathrm{C}$ reduced INPs active at $-12{ }^{\circ} \mathrm{C}$ by $70-98 \%$ while in three of the four agricultural soils tested by O'Sullivan et al. (2014) a $90^{\circ} \mathrm{C}$ treatment reduced INPs active at -10 to $-12^{\circ} \mathrm{C}$ by around 10 -fold.

\subsection{IN bacteria}

Lysozyme had a minimal overall impact upon INP concentrations but did reduce INPs active at $\geq-6$ or $\geq-7.5^{\circ} \mathrm{C}$, apart from in the lodgepole pine soil (Fig. 6). In this respect - its affect on high-temperature-active INPs - it generally corresponds to the findings of Christner et al. (2008), of lysozyme-sensitive material accounting for 50 and $25 \%$ of INPs active $\geq-9^{\circ} \mathrm{C}$ in precipitation samples from Montana and Louisiana respectively. The bacteria deactivated by the lysozyme may have included the known IN bacteria at levels below the detection limits of the PCR test (see below) and/or other IN bacterial species.

Evidence exists both for and against the occurrence of IN bacteria (species of Pseudomonas, Pantoea, and Xanthomonas) as natural components of the soil microflora. They have been isolated at $\approx 10^{5} \mathrm{~g}^{-1}$ from surface field soil (Lindemann et al., 1982), and IN Ps. borealis was reported as a natural component of Arctic tundra topsoil (Wilson et al., 

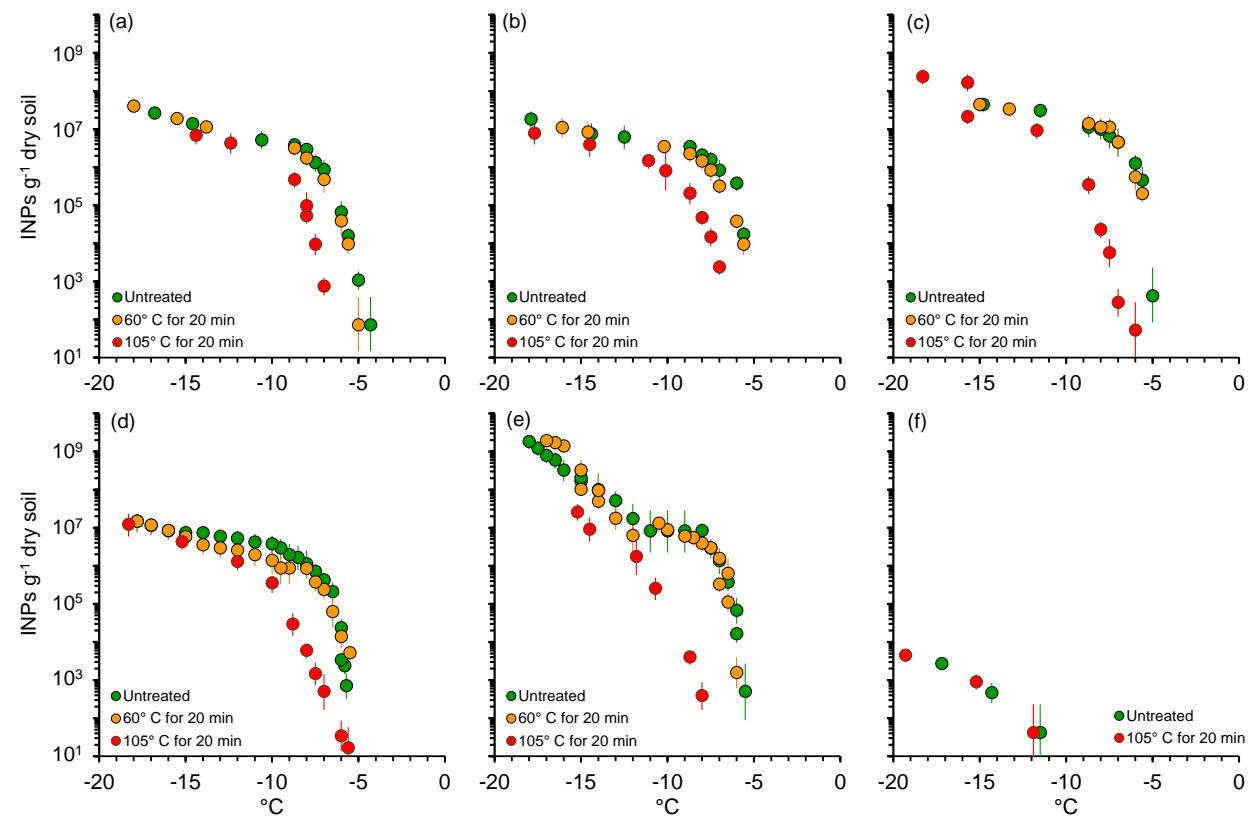

Figure 5. Effect of heating in water to $105^{\circ} \mathrm{C}$ upon INPs in soils. Soils are (a) sugar beet, (b) organic grass/alfalfa fallow, (c) pasture, (d) sagebrush shrubland, (e) lodgepole pine forest, and (f) pure kaolinite.
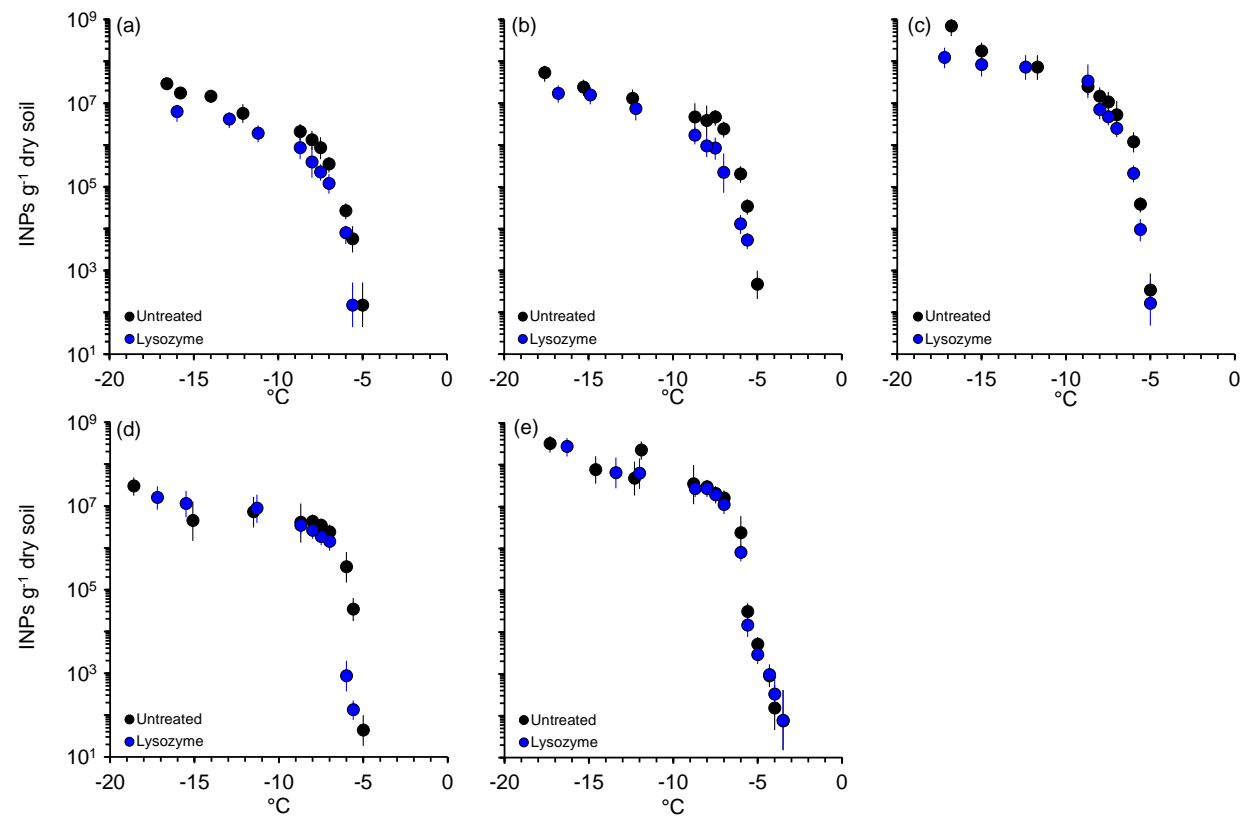

Figure 6. Effect of lysozyme digestion upon soil INPs. Soils are (a) sugar beet, (b) organic grass/alfalfa fallow, (c) pasture, (d) sagebrush shrubland, and (e) lodgepole pine forest.

2006). Garcia et al. (2012) also found $\approx 10^{5}$ ina genes $\mathrm{g}^{-1}$ in the surface soil of a just-harvested corn field, but it is possible these came from pulverized corn tissue dusting the surface. Vali et al. (1976) also demonstrated the ability of a locally isolated Ps. syringae to colonize leaf litter. By contrast, Conen et al. (2011) predicted that the contribution of IN bacteria to soil INPs would be negligible based on previous stud- ies showing that $P$ s. syringae typically did not survive more than a few weeks after addition to soils (e.g. McCarter et al., 1983; Goodnow et al., 1990). Even so, it is possible that their IN activity could be longer-lived if their Ina proteins are adsorbed onto clays.

Direct testing for the presence of IN bacteria, using PCR with primers designed to amplify most alleles of the ina gene 

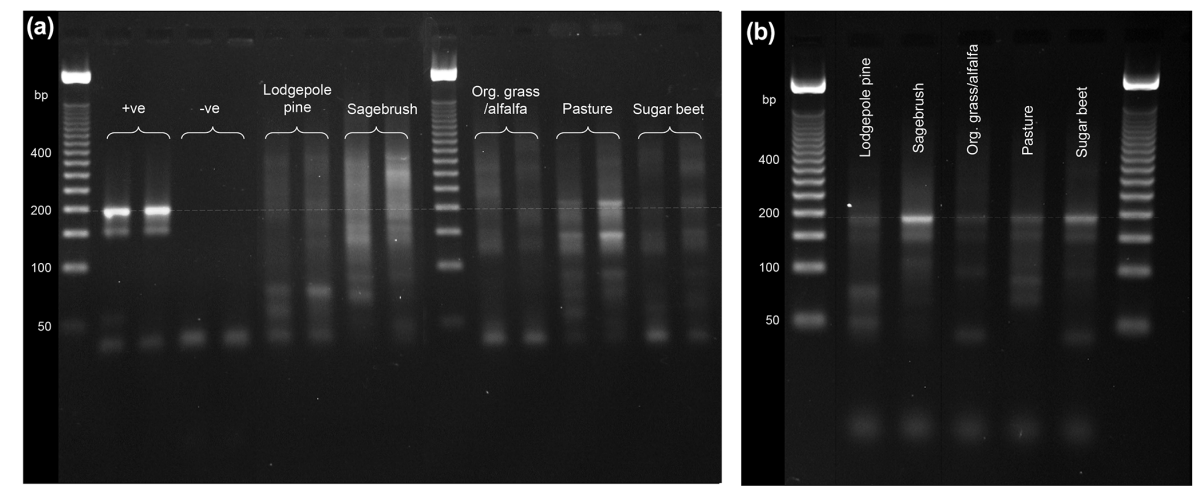

Figure 7. Test for ina gene presence in soil DNA. (a) No detectable ina gene amplicons (194 bp, as indicated by the faint dashed line) were discernable in any of the soils. (b) Soil DNA spiked with 60 ina gene copies. Amplicons were visible in all samples, although differing in intensity due to sub-optimal amplification in most.

(Hill et al., 2014), which codes for the ice-active Ina protein, did not detect them in any of the soil DNA extracts (Fig. 7a). When soil DNA was spiked with DNA from IN $P s$. syringae Cit7, the ina genes were readily amplified, although with somewhat limited sensitivity due to mis-priming and co-amplification of non-target DNA (Fig. 7b). Using spiking tests with a range of ina gene copies, the lower detection limits were determined. When these were expressed as a fraction of INPs, the IN bacteria accounted for 0.5 to $4 \%$ of INPs active at $-12{ }^{\circ} \mathrm{C}$ in the pasture and organic grass/alfalfa soils respectively $\left(-12^{\circ} \mathrm{C}\right.$ is the temperature at which a single Ina protein nucleates; Govindarajan and Lindow, 1988). Under optimal conditions, the proportion of IN bacteria with ice nucleation activity at $-10^{\circ} \mathrm{C}$ can be $10 \%$ or higher (Kim et al., 1987; Nemecek-Marshall et al., 1993; Attard et al., 2012). Even if the populations possessed a $10 \%$ frequency of nucleation, the IN bacteria would then only account for $<0.5 \%$ of INPs at $-12^{\circ} \mathrm{C}$.

It is possible that Ina proteins could accumulate in soil by being adsorbed onto clay and/or organic matter (Schnell, 1977; O'Sullivan et al., 2016), thereby being protected from enzymatic digestion. Accordingly, even a very small IN bacterial population could accumulate to exert a disproportionate influence upon the INP content of soils. This mechanism could also apply to other cell-free INPs.

\subsection{IN fungi}

Screening of fungi isolated from agricultural and natural ecotype topsoils in Wyoming (including several of the soils used in this study) found a single species of IN fungus, Mortierella alpina, to be widespread and also abundant in soils with fresh inputs of plant material (Fröhlich-Nowoisky et al., 2015). Mortierella alpina is a saprobe utilizing decaying organic matter (Wagner et al., 2013), and due to its ability to solubilize phosphorus also develops a mutualistic association with another fungal genus that forms mycorrhizal symbioses with sagebrush (Wicklow-Howard, 1994; Zhang et al., 2011). All 39 isolates tested by Fröhlich-Nowoisky et al. (2015) initiated freezing at -5 to $-6{ }^{\circ} \mathrm{C}$. They also typically released $10^{8}$ to $10^{9}$ small $(<10 \mathrm{~nm})$ INPs per gram fresh weight of mycelium that nucleated between -5 and $-8^{\circ} \mathrm{C}$ (see O'Sullivan et al., 2015). For the three most common clades, which occurred in agricultural and lodgepole pine forest soils, digestion of isolates with papain lowered the INP concentration by $\approx 3-4$ orders of magnitude (FröhlichNowoisky et al., 2015), suggesting the INP was a protein.

In this study, digestion with papain lowered INPs active $\geq-11^{\circ} \mathrm{C}$ in the organic grass/alfalfa, the pasture, and the sagebrush soils by $\geq 75 \%$ (Fig. 8). Indeed, in these soils its effect was comparable to that of $105^{\circ} \mathrm{C}$ heating. By contrast, papain only deactivated INPs active $\geq-7^{\circ} \mathrm{C}$ in the sugar beet soil and had no impact on lodgepole pine forest soil, even though IN $M$. alpina was readily isolated from both (Fröhlich-Nowoisky et al., 2015). This may have been because these soil samples had been stored frozen and had been taken at different times from those in the Fröhlich-Nowoisky et al. (2015) study, and because a high relative abundance obtained via dilution plating, which is heavily biased towards spores, does not automatically equate to a significant vegetative biomass (Warcup, 1957). Alternatively, the papainsusceptible INPs in the other three soils were not from $M$. alpina but from another source.

Several species of fungi from the genus Fusarium are also known to be IN (Pouleur et al., 1992; Richard et al., 1996). These species contain strains that are plant pathogens as well as saprophytes and are promoted by agricultural practices. Digestion of cultures of $F$. avenaceum and $F$. acuminatum with Proteinase K significantly reduced ice nucleation activity, suggesting that a protein is responsible (Hasegawa et al., 1994; Humphreys et al., 2001). In the agricultural soils tested, incubation with Proteinase $\mathrm{K}$ had a minimal affect upon overall INP concentrations. In the organic grass/alfalfa and sugar beet soils it reduced INPs active $\geq-6{ }^{\circ} \mathrm{C}$ by $\approx 10$-fold (Fig. 9), as would be expected for deactivation 

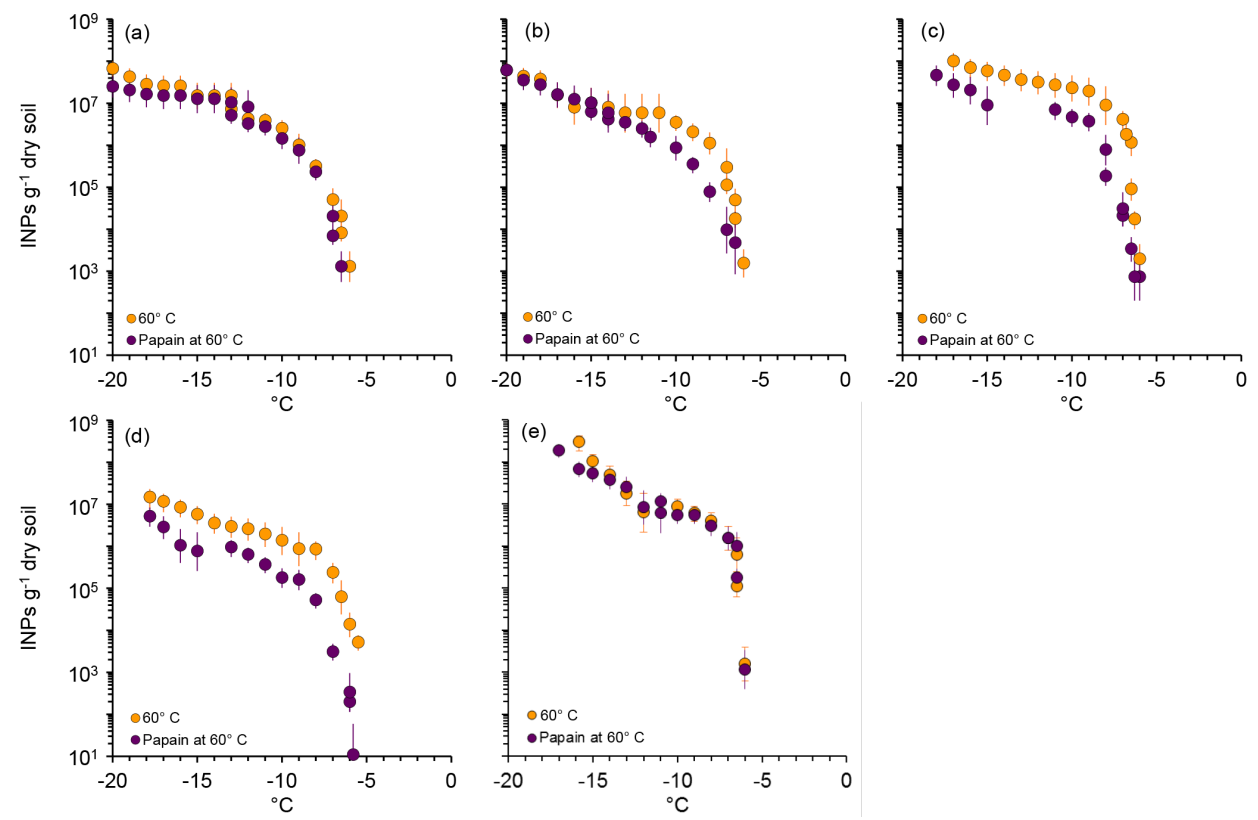

Figure 8. Effect of papain protease digestion upon INPs in soils. Soils are (a) sugar beet, (b) organic grass/alfalfa fallow, (c) pasture, (d) sagebrush shrubland, and (e) lodgepole pine forest.
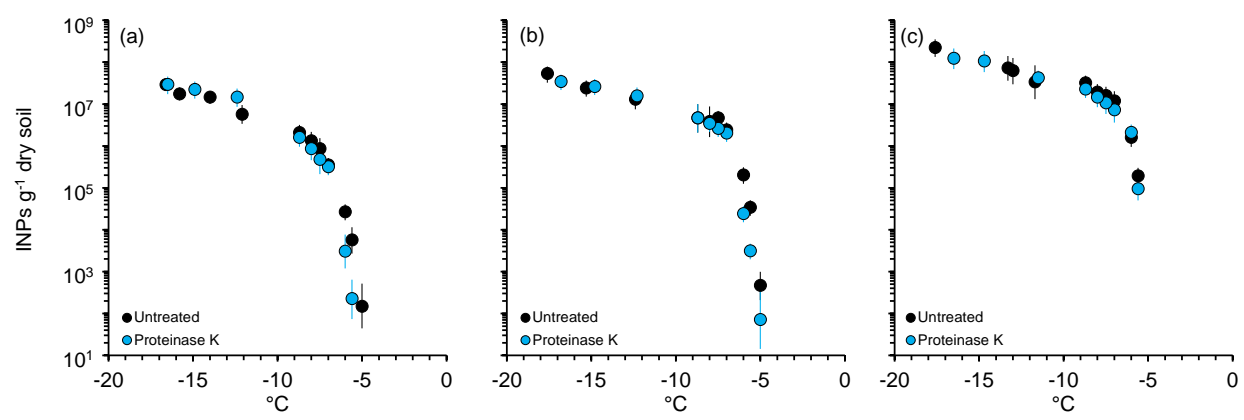

Figure 9. Effect of Proteinase K digestion upon INPs in soils. Soils are (a) sugar beet, (b) organic grass/alfalfa fallow, and (c) pasture.

of IN Fusarium (Hasegawa et al., 1994; Richard et al., 1996; Pouleur et al., 1992; Humphreys et al., 2001) and Mortierella, but it had no effect on the roadside pasture soil. The cultivated soils thus contained some Proteinase Ksensitive IN microflora.

\subsection{Direct isolation of INPs from sagebrush soil}

We present the first images of probable INPs directly isolated from soil. INPs active at $-7^{\circ} \mathrm{C}$ in the sagebrush shrubland soil were isolated by repeated cycles cooling an array of droplets to identify the INP-containing droplet, addition of de-ionized water to dilute that droplet, and its further subdivision and subsequent freeze testing. Starting with a $10^{-5}$ dilution of the soil suspension, a further 5-6 cycles of freezing and droplet subdivision were required to obtain a single visible particle in the evaporated droplet residue.
Two INPs were isolated. INP1 was roughly $20 \times 5 \mu \mathrm{m}$ and appeared to be a complex entity (Fig. 10a). After isolation and photography, INP1 was re-suspended in $1 \mu \mathrm{L}$ water, which was divided into four droplets and these freeze tested. This time two wells froze, and in all four droplets there were numerous fragments of the original piece (Fig. 10b). In sagebrush surface soils, freeze/thaw cycles occur frequently from mid-autumn to mid-spring, providing multiple opportunities for such fracturing and multiplication of INPs. INP2 appeared to be a roughly $30 \times 20 \mu \mathrm{m}$ piece of gel (Fig. 10c, d). It was partly squashed by capillary forces when mounted between slide and coverslip (Fig. 10d) and was semi-transparent. Although the matrix may have been mucilage secreted by roots (Foster et al., 1983), exopolysaccharide and alginate gels are also produced by microbes, and the two often intermix forming mucigels (Foster, 1986). The actual INP was potentially one of many things: either a component of the gel itself or one of its many inclusions. 


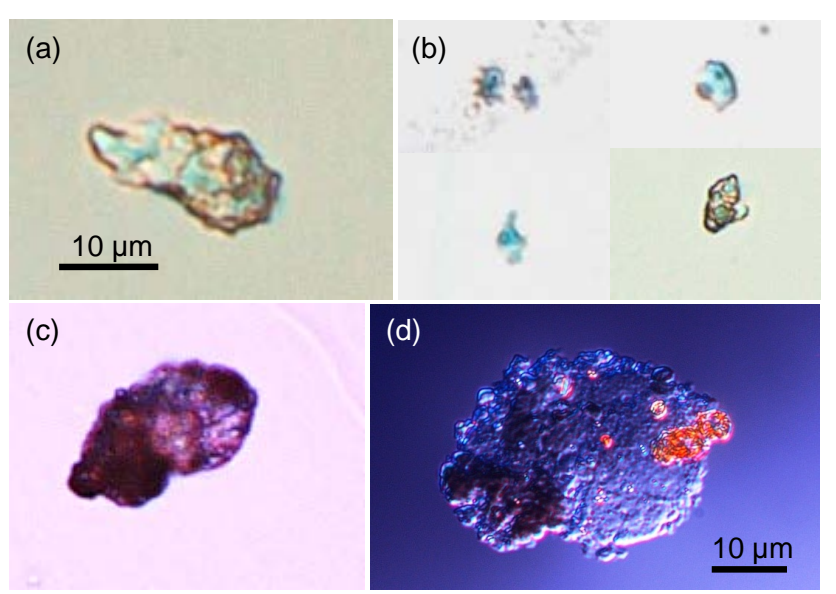

Figure 10. Ice nucleating particle, INP1, isolated from sagebrush soil (a). After six freeze-thaw cycles it fragmented into many small pieces, the larger fragments of which are shown in (b), creating at least two INPs (i.e. two droplets froze). Ice nucleating particle, INP2, in white light (c) and illuminated using differential interference contrast microscopy (blue polarized light was used simply to accentuate structural details, but the rust colour of the inclusions is natural, d).

Filtration tests of a sagebrush soil suspension showed that $68 \%$ of INPs active at $-7^{\circ} \mathrm{C}$ were $>5 \mu \mathrm{m}$ diameter and $88 \%>0.45 \mu \mathrm{m}$. Hence, the randomly selected INPs isolated here were also large. It is possible that the true INP was an accompanying component too small to be visible. However, the fragmentation of INP1 after six freeze/thaw cycles leading to the production of two INPs suggests that the large particle was indeed the source.

\subsection{Ice nucleation by sagebrush tissues}

The particularly pronounced onset of ice nucleation activity in sagebrush shrubland soil (Fig. 2) suggested a single class of IN material was responsible. Since Wyoming big sagebrush (Artemisia tridentata) contributes organic matter directly to the soil via leaf fall and the shedding of fine roots and root hairs, its tissues may be a direct source of these INPs. Indeed, powdered sagebrush shoots and roots contained a distinct and abundant class of INPs that nucleated at $\approx-12{ }^{\circ} \mathrm{C}$ (Fig. 11). The relatively warm temperature of activity of sagebrush tissue INPs suggests it may play a functional and protective role for the plant, although its onset temperature is much lower than that possessed by IN peach wood tissue $\left(\approx-2{ }^{\circ} \mathrm{C}\right.$, Gross et al., 1988). Interestingly, $A$. tridenta seedlings from comparable altitudes exhibited significant damage ( $>50 \%$ loss of potential function of Photosystem II) when chilled to between -12.5 and $-15^{\circ} \mathrm{C}$ (Loik and Redar, 2003), suggesting that sagebrush tissues may naturally supercool until being nucleated by these endogenous INPs. Heating to $105^{\circ} \mathrm{C}$ completely deactivated the INPs active at $\approx-12^{\circ} \mathrm{C}$. Likewise, they appeared to be lost upon
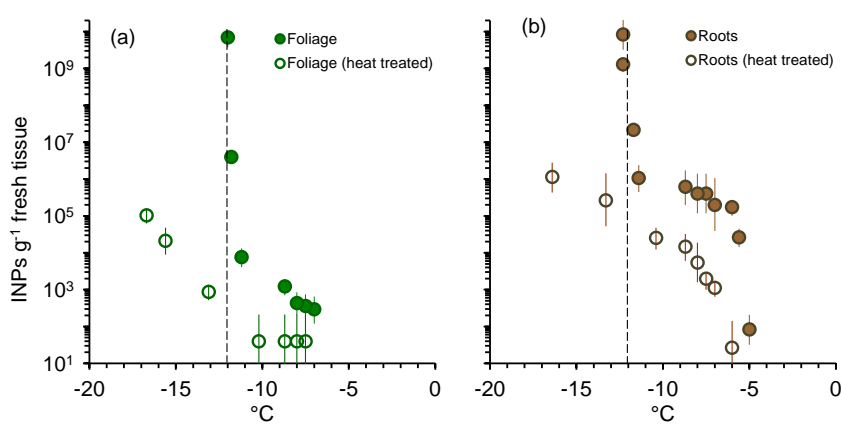

Figure 11. Ice nucleating particles in sagebrush shoot (a) and root (b) tissues ground under liquid nitrogen and after heating to $105^{\circ} \mathrm{C}$. The dashed line at $-12^{\circ} \mathrm{C}$ is a guide to indicate the temperature of freezing of the tissues.

decomposition, since there was no evidence of an increase in INPs active around this temperature in the soil (Fig. 2). Cellulose may also have contributed to the residual INP activity of the sagebrush tissue that remained after heating (Hiranuma et al., 2015a).

In addition to the highly active entity at $\approx-12{ }^{\circ} \mathrm{C}$, sagebrush roots also had a lesser class of INPs with a profile similar to that of the soil (Fig. 11b). This high-temperature group may have been contributed by the diverse microflora that colonizes roots, from soil biological material still attached to the epidermis of the roots after washing, or from arbuscular mycorrhizal fungi and other microflora inhabiting the root cortex (Watson, 1987). Notably, one of the few fungal genera that form a mycorrhizal symbiosis with sagebrush also develops a mutualistic association with M. alpina (Wicklow-Howard, 1994; Zhang et al., 2011).

\section{Conclusions}

Ice nucleating particles denatured by heating $\left(105^{\circ} \mathrm{C}\right) \mathrm{ac}-$ counted for most INPs active $>-10^{\circ} \mathrm{C}$. A range of entities both within the soil microflora and SOM will be heatlabile. Proteins will be denatured; molecular complexes, organelles and structures (e.g. ribosomes, flagella, membranes) entirely disrupted; crystals dissolved; and aggregates of storage polymers (e.g. polyhydroxyalkanoates) and lipid bodies dispersed. Immersion in hot water could also affect the IN ability of minerals. For example, the IN activity of K-feldspar (Atkinson et al., 2013) may be altered by a change in composition of surface ions (Zolles et al., 2015). However, the lack of any effect upon heating samples to $60^{\circ} \mathrm{C}$ suggests this was not the case (see also O'Sullivan et al., 2015).

While lysozyme and Proteinase $\mathrm{K}$ had minimal overall impacts upon INP concentrations, papain protease reduced INP numbers significantly in two agricultural soils and in the sagebrush shrubland soil, suggesting that in these a protein was responsible. This may have been due to the presence of M. alpina (Fröhlich-Nowoisky et al., 2015), but it equally 


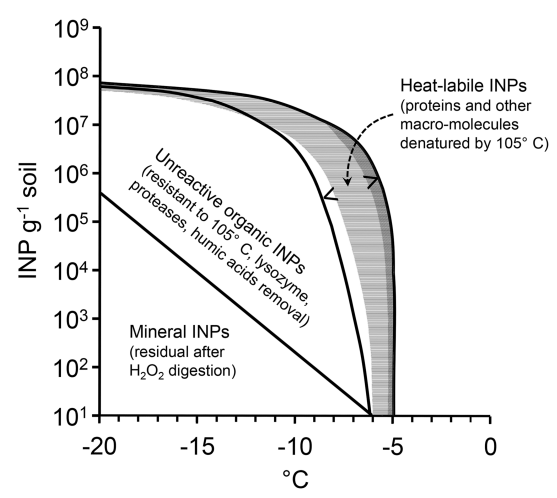

Figure 12. Sources of ice nucleating particles in the pasture soil. Within the heat-labile segment, horizontal lines indicate IN proteins digested by papain (e.g. from Mortierella alpina), and diagonal lines INPs in live bacteria (sensitive to lysis with lysozyme). The mineral INPs wedge is inherently approximate since $\mathrm{H}_{2} \mathrm{O}_{2}$ oxidation may not remove all SOM and cannot be assumed not to deactivate IN sites on some minerals.

may have been due to IN proteins from other microbes and/or the soil fauna (e.g. protozoa, mites, nematodes). The three enzymes have very specific sites of activity within their target molecules (lysozyme also hydrolyses fungal chitin oligosaccharides, but does not digest the chitin polymer itself) but may have also have had non-target influences. For example, enzymes may bind to and block INPs on mineral surfaces (see Zolles et al., 2015). Further, while reaction conditions for all enzymes were theoretically optimal, and ample time given for completion, their efficiencies are not guaranteed in such a complex milieu as soil; their substrates may have been protected by adsorption to clays (O'Sullivan et al., 2016) or tannins or by location within flocs or biofilms, and they themselves may have been inactivated by similar mechanisms or by cleavage by native proteases.

Two probable INPs were isolated by exploiting their IN activity (initially at $-7^{\circ} \mathrm{C}$ ). Since both were complex entities, the specific IN component was not able to be identified. Freeze fracturing of one into at least two INPs demonstrated that freeze-thaw cycles in topsoils could cause multiplication of INPs.

Figure 12 summarizes the classes of INPs in the pasture soil. With variations in proportions it can be used as a general summary of likely INP composition in arable and grassland topsoils. Notable is the segment of organic INPs active below -10 to $-12^{\circ} \mathrm{C}$ that was unaffected by any challenge short of oxidation with $\mathrm{H}_{2} \mathrm{O}_{2}$ (labelled "Unreactive organic INPs"). Their refractoriness can be used to rule out some potential sources:

- they are not proteins or peptides, due to their resistance to $105^{\circ} \mathrm{C}$ heating and insensitivity to papain and Proteinase $\mathrm{K}$ (they could be proteins protected by adsorp- tion onto clay, but this would not explain their presence in the lodgepole pine litter);

- they are not peptidoglycan from bacteria since they survived lysozyme digestion;

- they are unlikely to be chitin and related fungal cell wall polysaccharides since Pummer et al. (2013) found no appreciable ice nucleation activity above $-26^{\circ} \mathrm{C}$ in fungal spores from a range of common fungi (other than in a known IN Fusarium);

- they do not appear to be fulvic or humic acids.

Hence, they are some component/s of plant material, microbial biomass, and/or humin. Humin is comprised in large part of macromolecules or aggregates of peptides, aliphatics, peptidoglycan, carbohydrates, and lignin. Ruling out the first three leaves lignin or carbohydrates as possibilities. Lignin seems an unlikely candidate as an INP due to its disordered structure and relative hydrophobicity. Cellulose, a carbohydrate, may account for some of the activity colder than $-15^{\circ} \mathrm{C}$ (Hiranuma et al., 2015a).

The variable effectiveness of the challenge tests in different soils indicates that soil INPs come from a range of sources, occur with differing relative abundances, and may be protected by different mechanisms. For example, the complete insensitivity of INPs in the lodgepole pine forest litter to any tests other than heat and $\mathrm{H}_{2} \mathrm{O}_{2}$ digestion suggests that this population differs fundamentally from those in nonforest soils.

Since SOM comprises a diverse continuum of forms, ranging from fresh plant inputs to ancient inert organic matter, it should be expected that both the compositions and the intrinsic temperatures of nucleation of the INPs will be similarly broad. This can be inferred from the smooth curves of the INP temperature spectra, each being the sum of many underlying activity distributions. Organic INPs will also occur as organo-mineral complexes, which will presumably affect their activity and protect them by spatial isolation and adsorption onto clays (Schnell, 1977; Kögel-Knabner et al., 2008; O'Sullivan et al., 2016).

All soils, with the relative exception of ponderosa pine litter, were rich potential sources of organic, warmtemperature-active IN aerosols. Agricultural intensification in semi-arid regions of the western USA over the past 200 years has led to a more than 4-fold increase in atmospheric dustiness (Neff et al., 2008). The increased wind erosion also selectively removes the fine and light fractions, which are enriched in particles $<10 \mu \mathrm{m}$ in diameter and organic matter approximately 6-fold (Van Pelt and Zobeck, 2007). Biological particles, predominantly bacteria and fungi, accounted for an average of $40 \%$ of the organic carbon in particles $<10 \mu \mathrm{m}$ at Storm Peak Laboratory in western Colorado (Wiedinmyer et al., 2009) and were present in dust events intersecting the site (Hallar et al., 2011). INP emissions by these western 
US landscapes will thus be influenced by soils that are more prone to destabilization by both previous and current human activities.

Acknowledgements. We thank Jenna Meeks and Bob Baumgartner for access to the soils at SAREC, William Stump for advice concerning experimental farm soils, and Prakriti Bista for elemental analyses. We thank Pierre Amato, Russell Schnell, Daniel O'Sullivan, Gabor Vali and an anonymous reviewer for their very helpful reviews. This work was funded by National Science Foundation grants 1358495 (PD and TH), 0841542 (TH and GF), and 0841602 (PD). J. Fröhlich-Nowoisky acknowledges the Max Planck Society and the Ice Nuclei research Unit of the German Research Foundation (DFG FR3641/1-2, FOR 1525 INUIT) for project funding. Y. Tobo acknowledges the Japan Society for the Promotion of Science (JSPS) Postdoctoral Fellowships for Research Abroad, and JSPS KAKENHI grant number 15K13570.

Edited by: A. Huffman

\section{References}

Agresti, A. and Coull, B. A.: Approximate is better than "exact" for interval estimation of binomial proportions, Am. Stat., 52, 119126, 1998.

Atkinson, J. D., Murray, B. J., Woodhouse, M. T., Whale, T. F., Baustian, K. J., Carslaw, K. S., Dobbie, S., O'Sullivan D., and Malkin, T. L.: The importance of feldspar for ice nucleation by mineral dust in mixed-phase clouds, Nature, 498, 355-358, 2013.

Attard, E., Yang, H., Delort, A.-M., Amato, P., Pöschl, U., Glaux, C., Koop, T., and Morris, C. E.: Effects of atmospheric conditions on ice nucleation activity of Pseudomonas, Atmos. Chem. Phys., 12, 10667-10677, doi:10.5194/acp-12-10667-2012, 2012.

Bashkirova, G. M. and Krasikov, P. N.: Investigation of certain substances as reagents in crystallization reagents of supercooled fog, Trudy Glavnoi. Geofiz. Obs., 72, 118-126, 1957.

Bigg, E. K., Soubeyrand, S., and Morris, C. E.: Persistent aftereffects of heavy rain on concentrations of ice nuclei and rainfall suggest a biological cause, Atmos. Chem. Phys., 15, 2313-2326, doi:10.5194/acp-15-2313-2015, 2015.

Bowers, R. M., McLetchie, S., Knight, R., and Fierer, N.: Spatial variability in airborne bacterial communities across land-use types and their relationship to the bacterial communities of potential source environments, ISME J., 5, 601-612, 2010.

Christner, B. C., Cai, R., Morris, C. E., McCarter, K. S., Foreman, C. M., Skidmore, M. L., Montross, S. N., and Sands, D. C.: Geographic, seasonal, and precipitation chemistry influence on the abundance and activity of biological ice nucleators in rain and snow, P. Natl. Acad. Sci., 105, 18854-18859, 2008.

Coleman, K. and Jenkinson, D. S.: RothC-26.3 - A model for the turnover of carbon in soil: model description and windows users guide: November 1999 issue, Lawes Agricultural Trust, Harpenden, UK, 1999.

Conen, F., Morris, C. E., Leifeld, J., Yakutin, M. V., and Alewell, C.: Biological residues define the ice nucleation properties of soil dust, Atmos. Chem. Phys., 11, 9643-9648, doi:10.5194/acp-119643-2011, 2011.
Delort, A.-M., Vaïtilingom, M., Amato, P., Sancelme, M., Parazols, M., Mailhot, G., Laj, P., and Deguillaume, L.: A short overview of the microbial population in clouds: Potential roles in atmospheric chemistry and nucleation processes, Atmos. Res., 98, 249-260, 2010.

De Vos, B., Vandecasteele, B., Deckers, J., and Muys, B.: Capability of loss-on-ignition as a predictor of total organic carbon in noncalcareous forest soils, Commun. Soil Sci. Plan., 36, 2899-2921, 2005.

Feczko, T., Puxbaum, H., Kasper-Giebl, A., Handler, M., Limbeck, A., Gelencsér, A., Pio, C., Preunkert S., and Legrand, M.: Determination of water and alkaline extractable atmospheric humiclike substances with the TU Vienna HULIS analyzer in samples from six background sites in Europe, J. Geophys. Res., 112, D23S10, doi:10.1029/2006JD008331, 2007.

Fornea, A. P., Brooks, S. D., Dooley, J. B., and Saha, A.: Heterogeneous freezing of ice on atmospheric aerosols containing ash, soot, and soil, J. Geophys. Res., 114, D13201, doi:10.1029/2009JD011958, 2009.

Foster, R. C.: The ultrastructure of the rhizoplane and rhizosphere, Annu. Rev. Phytopathol., 24, 211-234, 1986.

Foster, R. C., Rovira, A. D., and Cock, T. W.: Ultrastructure of the root-soil interface, Am. Phytopathol. Soc, St. Paul, MN, 157 pp., 1983.

Fröhlich-Nowoisky, J., Hill, T. C. J., Pummer, B. G., Yordanova, P., Franc, G. D., and Pöschl, U.: Ice nucleation activity in the widespread soil fungus Mortierella alpina, Biogeosciences, 12, 1057-1071, doi:10.5194/bg-12-1057-2015, 2015.

Fukuta, N.: Experimental studies of organic ice nuclei, J. Atmos. Sci., 23, 191-196, 1966.

Fukuta, N. and Mason, B. J.: Epitaxial growth of ice on organic crystals, J. Phys. Chem. Solids, 24, 715-718, 1963.

Garcia, E., Hill, T. C. J., Prenni, A. J., DeMott, P. J., Franc, G. D., and Kreidenweis, S. M.: Biogenic ice nuclei in boundary layer air over two U.S. High Plains agricultural regions, J. Geophys. Res., 117, D18209, doi:10.1029/2012JD018343, 2012.

Garnham, C. P., Campbell, R. L., Walker, V. K., and Davies, P. L.: Novel dimeric $\beta$-helical model of an ice nucleation protein with bridged active sites, BMC Struct. Biol., 11, 36, doi:10.1186/1472-6807-11-36, 2011.

Gavish, M., Popovitz-Biro, R., Lahav, M., and Leiserowitz, L.: Ice nucleation by alcohols arranged in monolayers at the surface of water drops, Science, 250, 973-975, 1990.

Goodnow, R. A., Harrison, M. D., Morris, J. D., Sweeting, K. B., and Laduka, R. J.: Fate of ice nucleation-active Pseudomonas syringae strains in alpine soils and waters and in synthetic snow samples, Appl. Environ. Microbiol., 56, 2223-2227, 1990.

Govindarajan, A. G. and Lindow, S. E.: Size of bacterial icenucleation sites measured in situ by radiation inactivation analysis, P. Natl. Acad. Sci. USA, 85, 1334-1338, 1988.

Graber, E. R. and Rudich, Y.: Atmospheric HULIS: How humic-like are they? A comprehensive and critical review, Atmos. Chem. Phys., 6, 729-753, doi:10.5194/acp-6-729-2006, 2006.

Gross, D. C., Proebsting, E. L. Jr., and MacCrindle-Zimmerman, H.: Development, distribution, and characteristics of intrinsic, nonbacterial ice nuclei in Prunus wood, Plant Physiol., 88, 915-922, 1988.

Hallar, A. G., Chirokova, G., McCubbin, I., Painter, T. H., Wiedinmyer, C., and Dodson, C.: Atmospheric bioaerosols transported 
via dust storms in the western United States, Geophys. Res. Lett., 38, L17801, doi:10.1029/2011GL048166, 2011.

Hasegawa, Y., Ishihara, Y., and Tokuyama, T.: Characteristics of ice-nucleation activity in Fusarium avenaceum IFO 7158, Biosci. Biotech. Biochem., 58, 2273-2274, 1994.

Head, R. B.: Steroids as ice nucleators, Nature, 191, 1058-1059, 1961.

Head, R. B.: Ice nucleation by some cyclic compounds, J. Phys. Chem. Solids, 23, 1371-1378, 1962.

Hill, T. C. J., Georgakopoulos, D. G., DeMott, P. J., Stump, W. L., and Franc, G. D.: Measurement of ice nucleation-active bacteria on plants and in precipitation by quantitative PCR, Appl. Environ. Microbiol., 80, 256-1267, 2014.

Hiranuma, N., Möhler, O., Yamashita, K., Tajiri, T., Saito, A., Kiselev, A., Hoffmann, N., Hoose, C., Jantsch, E., Koop T., and Murakami, M.: Ice nucleation by cellulose and its potential contribution to ice formation in clouds, Nat. Geosci., 8, 273-277, $2015 \mathrm{a}$.

Hiranuma, N., Augustin-Bauditz, S., Bingemer, H., Budke, C., Curtius, J., Danielczok, A., Diehl, K., Dreischmeier, K., Ebert, M., Frank, F., Hoffmann, N., Kandler, K., Kiselev, A., Koop, T., Leisner, T., Möhler, O., Nillius, B., Peckhaus, A., Rose, D., Weinbruch, S., Wex, H., Boose, Y., DeMott, P. J., Hader, J. D., Hill, T. C. J., Kanji, Z. A., Kulkarni, G., Levin, E. J. T., McCluskey, C. S., Murakami, M., Murray, B. J., Niedermeier, D., Petters, M. D., O’Sullivan, D., Saito, A., Schill, G. P., Tajiri, T., Tolbert, M. A., Welti, A., Whale, T. F., Wright, T. P., and Yamashita, K.: A comprehensive laboratory study on the immersion freezing behavior of illite NX particles: a comparison of 17 ice nucleation measurement techniques, Atmos. Chem. Phys., 15, 2489-2518, doi:10.5194/acp-15-2489-2015, 2015 b.

Huffman, J. A., Prenni, A. J., DeMott, P. J., Pöhlker, C., Mason, R. H., Robinson, N. H., Fröhlich-Nowoisky, J., Tobo, Y., Després, V. R., Garcia, E., Gochis, D. J., Harris, E., Müller-Germann, I., Ruzene, C., Schmer, B., Sinha, B., Day, D. A., Andreae, M. O., Jimenez, J. L., Gallagher, M., Kreidenweis, S. M., Bertram, A. K., and Pöschl, U.: High concentrations of biological aerosol particles and ice nuclei during and after rain, Atmos. Chem. Phys., 13, 6151-6164, doi:10.5194/acp-13-6151-2013, 2013.

Humphreys, T. L., Castrillo, L. A., and Lee, M. R.: Sensitivity of partially purified ice nucleation activity of Fusarium acuminatum SRSF 616, Curr. Microbiol., 42, 330-338, 2001.

Joly, M., Amato, P., Deguillaume, L., Monier, M., Hoose, C., and Delort, A.-M.: Quantification of ice nuclei active at near $0{ }^{\circ} \mathrm{C}$ temperatures in low-altitude clouds at the Puy de Dôme atmospheric station, Atmos. Chem. Phys., 14, 8185-8195, doi:10.5194/acp-14-8185-2014, 2014.

Kanji, Z. A., Florea, O., and Abbatt, J. P.: Ice formation via deposition nucleation on mineral dust and organics: dependence of onset relative humidity on total particulate surface area, Environ. Res. Lett., 3, 025004, doi:10.1088/1748-9326/3/2/025004, 2008.

Kieft, T. L. and Ruscetti, T.: Characterization of biological ice nuclei from a lichen, J. Bacteriol., 172, 3519-3523, 1990

Kim, H. K., Orser, C., Lindow, S. E., and Sands, D. C.: Xanthomonas campestris pv. translucens strains active in ice nucleation, Plant Dis., 71, 994-997, 1987.

Kögel-Knabner, I., Guggenberger, G., Kleber, M., Kandeler, E., Kalbitz, K., Scheu, S., Eusterhues K., and Leinweber, P.: Organomineral associations in temperate soils: integrating biology, min- eralogy, and organic matter chemistry, Z. Pflanz. Bodenkunde, 171, 61-82, 2008.

Kozloff, L. M., Turner, M. A., Arellano, F., and Lute, M.: Formation of bacterial membrane ice-nucleating lipoglycoprotein complexes, J. Bacteriol., 173, 6528-6536, 1991.

Lindemann, J., Constantinidou, H. A., Barchet, W. R., and Upper, C. D.: Plants as sources of airborne bacteria, including ice nucleation-active bacteria, Appl. Environ. Microbiol., 44, 10591063, 1982.

Loik, M. E. and Redar, S. P.: Microclimate, freezing tolerance, and cold acclimation along an elevation gradient for seedlings of the Great Basin Desert shrub, Artemisia tridentate, J. Arid Environ., 54, 769-782, 2003.

Maki, L. R., Galyan, E. L., Chang-Chien, M.-M., and Caldwell, D. R.: Ice nucleation induced by Pseudomonas syringae, Appl. Microbiol., 28, 456-459, 1974.

Mason, R. H., Si, M., Li, J., Chou, C., Dickie, R., Toom-Sauntry, D., Pöhlker, C., Yakobi-Hancock, J. D., Ladino, L. A., Jones, K., Leaitch, W. R., Schiller, C. L., Abbatt, J. P. D., Huffman, J. A., and Bertram, A. K.: Ice nucleating particles at a coastal marine boundary layer site: correlations with aerosol type and meteorological conditions, Atmos. Chem. Phys., 15, 12547-12566, doi:10.5194/acp-15-12547-2015, 2015.

McCarter, S. M., Jones, J. B., Gitaitis, R. D., and Smitley, D. R.: Survival of Pseudomonas syringae pv. tomato in association with tomato seed, soil, host tissue and epiphytic weed host in Georgia, Phytopathology, 73, 1393-1398, 1983.

Mikutta, R., Kleber, M., Kaiser, K., and Jahn, R.: Review: Organic matter removal from soils using hydrogen peroxide, sodium hypochlorite, and disodium peroxodisulfate, Soil Sci. Soc. Am. J., 69, 120-135, 2005.

Monteil, C. L., Bardin, M., and Morris, C. E.: Features of air masses associated with the deposition of Pseudomonas syringae and Botrytis cinerea by rain and snowfall, ISME J., 8, 1-15, 2014.

Moore, R.: Soil survey of Pike National Forest, eastern part, Colorado, parts of Douglas, El Paso, Jefferson, and Teller counties, US Gov. Print. Office, Washington, DC, 1992.

Morris, C. E., Sands, D. C., Vinatzer, B. A., Glaux, C., Guilbaud, C., Buffière, A., Yan, S., Dominguez, H., and Thompson, B. M.: The life history of the plant pathogen Pseudomonas syringae is linked to the water cycle, ISME J., 2, 321-334, 2008.

Nemecek-Marshall, M., Laduca, R., and Fall, R.: High level expression of ice nuclei in a Pseudomonas syringae strain is induced by nutrient limitation and low temperature, J. Bacteriol., 175, 40624070, 1993.

Neff, J. C., Ballantyne, A. P., Farmer, G. L., Mahowald, N. M., Conroy, J. L., Landry, C. C., Overpeck, J. T., Painter, T. H., Lawrence, C. R., and Reynolds, R. L.: Increasing eolian dust deposition in the western United States linked to human activity, Nat. Geosci., 1, 189-195, 2008.

Ortega, J., Turnipseed, A., Guenther, A. B., Karl, T. G., Day, D. A., Gochis, D., Huffman, J. A., Prenni, A. J., Levin, E. J. T., Kreidenweis, S. M., DeMott, P. J., Tobo, Y., Patton, E. G., Hodzic, A., Cui, Y. Y., Harley, P. C., Hornbrook, R. S., Apel, E. C., Monson, R. K., Eller, A. S. D., Greenberg, J. P., Barth, M. C., CampuzanoJost, P., Palm, B. B., Jimenez, J. L., Aiken, A. C., Dubey, M. K., Geron, C., Offenberg, J., Ryan, M. G., Fornwalt, P. J., Pryor, S. C., Keutsch, F. N., DiGangi, J. P., Chan, A. W. H., Goldstein, A. H., Wolfe, G. M., Kim, S., Kaser, L., Schnitzhofer, R., Hansel, 
A., Cantrell, C. A., Mauldin, R. L., and Smith, J. N.: Overview of the Manitou Experimental Forest Observatory: site description and selected science results from 2008 to 2013, Atmos. Chem. Phys., 14, 6345-6367, doi:10.5194/acp-14-6345-2014, 2014.

O'Sullivan, D., Murray, B. J., Malkin, T. L., Whale, T. F., Umo, N. S., Atkinson, J. D., Price, H. C., Baustian, K. J., Browse, J., and Webb, M. E.: Ice nucleation by fertile soil dusts: relative importance of mineral and biogenic components, Atmos. Chem. Phys., 14, 1853-1867, doi:10.5194/acp-14-1853-2014, 2014.

O'Sullivan, D., Murray, B. J., Ross, J. F., Whale, T. F., Price, H. C., Atkinson, J. D., Umo, N. S., and Webb, M. E.: The relevance of nanoscale biological fragments for ice nucleation in clouds, Sci. Rep., 5, 8082, doi:10.1038/srep08082, 2015.

O'Sullivan, D., Murray, B. J., Ross, J., and Webb, M. E.: The adsorption of fungal ice-nucleating proteins on mineral dusts: a terrestrial reservoir of atmospheric ice-nucleating particles, Atmos. Chem. Phys. Discuss., doi:10.5194/acp-2015-1018, in review, 2016.

Petters, M. D. and Wright, T. P.: Revisiting ice nucleation from precipitation samples, Geophys. Res. Lett., 42, 8758-8766, 2015.

Pooley, L. and Brown, T. A.: Preparation of active cell-free ice nuclei from Pseudomonas syringae, P. R. Soc. Lond. B Bio., 241, 112-115, 1990.

Popovitz-Biro, R., Lahav, M., and Leiserowitz, L.: Ice nucleation: A test to probe the packing of amphiphilic alcohols at the oil-water interface, J. Am. Chem. Soc., 113, 8943-8944, 1991.

Popovitz-Biro, R., Wang, J. Majewski, J., Shavit, E., Leiserowitz, L., and Lahav, M.: Induced freezing of supercooled water into ice by self-assembled crystalline monolayers of amphiphilic alcohols at the air-water interface, J. Amer. Chem. Soc., 116, 11791191, 1994.

Pouleur, S., Richard, C., Martin, J.-G., and Antoun, H.: Ice nucleation activity in Fusarium acuminatum and Fusarium avenaceum, Appl. Environ. Microbiol., 58, 2960-2964, 1992.

Powlson, D., Smith, P., and De Nobili, M.: Soil organic matter, in: Soil Conditions and Plant Growth, edited by: Gregory, P. J. and Nortcliff, S., Blackwell Publishing Ltd, Oxford, UK, 86-131, 2013.

Prenni, A., Petters, M., Kreidenweis, S., Heald, C., Martin, S., Artaxo, P., Garland, R., Wollny, A., and Pöschl, U.: Relative roles of biogenic emissions and Saharan dust as ice nuclei in the Amazon basin, Nat. Geosci., 2, 402-405, 2009.

Prenni, A. J., Tobo, Y., Garcia, E., DeMott, P. J., McCluskey, C., Kreidenweis, S. M., Prenni, J., Huffman, A., Pöschl, U., and Pöhlker, C: The impact of rain on ice nuclei populations at a forested site in Colorado, Geophys. Res. Lett., 40, 227-231, 2013.

Pummer, B. G., Atanasova, L., Bauer, H., Bernardi, J., Druzhinina, I. S., Fröhlich-Nowoisky, J., and Grothe, H.: Spores of many common airborne fungi reveal no ice nucleation activity in oil immersion freezing experiments, Biogeosciences, 10, 80838091, doi:10.5194/bg-10-8083-2013, 2013.

Pummer, B. G., Budke, C., Augustin-Bauditz, S., Niedermeier, D., Felgitsch, L., Kampf, C. J., Huber, R. G., Liedl, K. R., Loerting, T., Moschen, T., Schauperl, M., Tollinger, M., Morris, C. E., Wex, H., Grothe, H., Pöschl, U., Koop, T., and FröhlichNowoisky, J.: Ice nucleation by water-soluble macromolecules, Atmos. Chem. Phys., 15, 4077-4091, doi:10.5194/acp-15-4077$2015,2015$.
Rao, M. A., Violante, A., and Gianfreda, L.: Interaction of acid phosphatase with clays, organic molecules and organo-mineral complexes: kinetics and stability, Soil Biol. Biochem., 32, 10071014, 2000.

Richard, C., Martin, J., and Pouleur, S.: Ice nucleation activity identified in some phytopathogenic Fusarium species, Phytoprotection, 77, 83-92, 1996.

Rosinski, J.: Heterogeneous nucleation of ice on surfaces of liquids, J. Phys. Chem., 84, 1829-1832, 1980.

Rosinski, J., Nagamoto, C. T., Kerrigan, T. C., and Langer, G.: Reply, J. Atmos. Sci., 31, 1459-1464, 1974.

Šantl-Temkiv, T., Sahyoun, M., Finster, K., Hartmann, S., Augustin, S., Stratmann, F., Wex, H., Clauss, T., Nielsen, N. W., Sørensen, J. H., Korsholm, U. S., Wick, L. Y., and Karlson, U. G.: Characterization of airborne ice-nucleation-active bacteria and bacterial fragments, Atmos. Environ., 109, 105-117, 2015.

Schmid, D., Pridmore, D., Capitani, G., Battistutta, R., Neeser, J.R., and Jann, A.: Molecular organisation of the ice nucleation protein InaV from Pseudomonas syringae, FEBS Lett., 414, 590-594, 1997.

Schnell, R. C.: Kaolin and a biogenic ice nucleant: some nucleation and identification studies, in: Proceedings of the IXth Nucleation Conference, Galway, Ireland, September 1977, 353-357, 1977.

Schnell, R. C. and Vali, G.: Atmospheric ice nuclei from decomposing vegetation, Nature, 236, 163-165, 1972.

Schnell, R. C. and Vali, G.: Worldwide source of leaf-derived freezing nuclei, Nature, 246, 212-213, 1973.

Schnell, R. C. and Vali, G.: Biogenic ice nuclei: Part I. terrestrial and marine sources, J. Atmos. Sci., 33, 1554-1564, 1976.

Simpson, A. J., Song, G., Smith, E., Lam, B., Novotny E. H., and Hayes, M. H. B.: Unraveling the structural components of soil humin by use of solution-state nuclear magnetic resonance spectroscopy, Environ. Sci. Technol., 41, 876-883, 2007.

Swift, R. S.: Organic matter characterization, in: Methods of soil analysis, Part 3 - chemical methods, edited by: Sparks, D. L., Page, A. L., Helmke, P. A., Loeppert, R. H., Soltanpour, P. N., Tabatabai, M. A., Johnston, C. T., and Sumner, M. E., Soil Science Society of America, Madison, WI, 1018-1020, 1996.

Tobo, Y., Prenni, A. J., DeMott, P. J, Huffman, J. A., McCluskey, C. S., Tian, G. X., Pöhlker, C., Pöschl, U., and Kreidenweis, S. M.: Biological aerosol particles as a key determinant of ice nuclei populations in a forest ecosystem, J. Geophys. Res., 118, 1010010110, 2013.

Tobo, Y., DeMott, P. J., Hill, T. C. J., Prenni, A. J., SwobodaColberg, N. G., Franc, G. D., and Kreidenweis, S. M.: Organic matter matters for ice nuclei of agricultural soil origin, Atmos. Chem. Phys., 14, 8521-8531, doi:10.5194/acp-14-8521-2014, 2014.

Turner, M. A., Arellano, F., and Kozloff, L. M.: Three separate classes of bacterial ice nucleation structures, J. Bacteriol., 172, 2521-2526, 1990.

United States Department of Agriculture: Soil survey of Goshen County, south part, Wyoming, Soil Conservation Service, 102 pp., 1971.

United States Department of Agriculture: Soil survey of Albany County Area, Wyoming, Natural Resources Conservation Service, US Government Printing Office, 540 pp., 1998. 
Vali, G.: Ice nucleation relevant to hail formation, Stormy Weather Group Scientific Report MW-58, McGill University, Montreal, Canada, 51 pp., 1968.

Vali, G.: Quantitative evaluation of experimental results on the heterogeneous freezing nucleation of supercooled liquids, J. Atmos. Sci., 28, 402-409, 1971.

Vali, G., Christensen, M., Fresh, R. W., Galyan, E. L., Maki, L. R., and Schnell, R. C.: Biogenic ice nuclei. II. Bacterial Sources, J. Atmos. Sci., 33, 1565-1570, 1976.

Van Pelt, R. S. and Zobeck, T. M.: Chemical constituents of fugitive dust, Environ. Monit. Assess., 130, 3-16, 2007.

Wagner, L., Stielow, B., Hoffmann, K., Petkovits, T., Papp, T., Vágvölgyi, C., de Hoog, G. S., Verkley, G., and Voigt, K.: A comprehensive molecular phylogeny of the Mortierellales (Mortierellomycotina) based on nuclear ribosomal DNA, Persoonia, Mol. Phylogeny Evol. Fungi, 30, 77-93, 2013.

Wander, M. M.: Soil organic matter fractions and their relevance to soil function, in: Advances in Agroecology, edited by: Magdoff, F. and Weil, R., CRC Press, Boca Raton, FL, 67-102, 2004.

Wang, B. and Knopf, D. A.: Heterogeneous ice nucleation on particles composed of humic-like substances impacted by $\mathrm{O}_{3}$, J. Geophys. Res., 116, D03205, doi:10.1029/2010JD014964, 2011.

Warcup, J. H.: Studies on the occurrence and activity of fungi in a wheat-field soil, T. Brit. Mycol. Soc., 40, 237-259, 1957.

Warren, G. J.: Identification and analysis of ina genes and proteins, in: Biological Ice Nucleation and Its Applications, edited by: Lee, R. E., Warren, G. J., and Gusta, L. V., American Phytopathological Society Press, St. Paul, MN, 85-99, 1995.
Watson, D. M. H.: Vesicular-arbuscular mycorrhizae of sagebrush (Artemisia spp.) in southeast Wyoming, MS thesis, University of Wyoming, WY, 1987.

Wicklow-Howard, M. C.: Vesicular-arbuscular mycorrhizae from sagebrush steppe habitat in western Idaho and parts of eastern and central Oregon, Report prepared for Eastside Ecosystem Management Project, Boise State University, Boise, ID, 37 pp., 1994.

Wiedinmyer, C., Bowers, R. M., Fierer, N., Horanyi, E., Hannigan, M., Hallar, A. G., McCubbin, I., and Baustian, K.: The contribution of biological particles to observed particulate organic carbon at a remote high altitude site, Atmos. Environ., 43, 4278-4282, 2009.

Wilson, S. L., Kelley D. L., and Walker, V. K.: Ice-active characteristics of soil bacteria selected by ice-affinity, Environ. Microbiol., 8, 1816-1824, 2006.

Wright, T. P., Hader, J. D., McMeeking G. R., and Petters, M. D.: High relative humidity as a trigger for widespread release of ice nuclei, Aerosol Sci. Tech., 48, i-v, doi:10.1080/02786826.2014.968244, 2014.

Zhang, H., Wu, X., Li, G., and Qin, P.: Interactions between arbuscular mycorrhizal fungi and phosphate-solubilizing fungus (Mortierella sp.) and their effects on Kostelelzkya virginica growth and enzyme activities of rhizosphere and bulk soils at different salinities, Biol. Fertil. Soils, 47, 543-54, 2011.

Zolles, T., Burkart, J., Häusler, T., Pummer, B., Hitzenberger, R., and Grothe, H.: Identification of ice nucleation active sites on feldspar dust particles, J. Phys. Chem. A, 119, 2692-2700, 2015. 